\title{
Verdenskrøniken 1812 som verdenslitteraturhistorie
}

\author{
Af Flemming Lundgreen-Nielsen
}

Grundtvigs $V K 1812$ er en universalhistorie, men den gemmer også med sammenlagt lidt over en femtedel af siderne en verdenslitteraturhistorie, den første skrevet på dansk af en enkeltperson. De talrige litteraturhistoriske afsnit, der rækker fra Kains efterkommere til Danmark-Norge i 1812, er imidlertid ikke markeret selvstændigt i trykket. De gennemgås i deres egen orden med citater af nøgleord og -udtryk og en del nutidige enkeltkommentarer tilsat. Skønt de kortfattede karakteristikker af digtere ofte er myter om forfald og fald, løber værket ud i grundlæggelsen af en ny litteratur i Norden lige efter 1802 i kølvandet på Steffens, Oehlenschläger og Grundtvig selv. Det romantiske gennembrud, der først i 1870'rne, 80'erne og 90'erne accepteres af litteraturforskere som Kr. Arentzen, Valdemar Vedel og Vilh. Andersen, er til stede som et bøjningsmønster allerede i 1812. Denne hele konstruktion er blevet overskygget af de mange mere iøjnefaldende og udfordrende træk ved krøniken, men fortjener en besindig opmærksomhed.

\section{Eldste danske verdenslitteraturhistorie}

Kort Begreb af Verdens Krønike i Sammenhoeng, 1812, er en righoldig og alsidig bog. I sig skjuler bindet faktisk den første trykte verdenslitteraturhistorie, som er skrevet på dansk af én og samme forfatter. ${ }^{1}$

Af de 422 sider i originaludgaven af $V K 1812$ beskæftiger ca. 94 sig nemlig med digtning (22,2\%). Den oprindelige tekst omfatter 363 sider, hvoraf ca. 79 er litteraturhistoriske $(21,7 \%)$, og senere "Rettelser og Anmærkninger" andrager yderligere 58 sider, hvoraf ca. 15 omhandler litteraturhistorie (25,8\%). ${ }^{2}$ Kategorien “Anmærkninger" betyder ofte tilføjelser.

Pagineringen af bogen er dog fortløbende, ligesom de litteraturhistoriske afsnit ikke typografisk er skilt ud fra det øvrige indhold. En lang række fakta signaleres generelt ved årstal i sidernes ydermarginer, men

\footnotetext{
${ }^{1}$ Senere mere eller mindre subjektivt styrede og bevidst populariserende énmandsredegørelser på dansk omfatter Sigurd Müllers Omrids af Verdensliteraturens Historie, 1881, Anna Erslevs Lidt om Verdenslitteraturen, 1894, Paul V. Rubows Verdenslitteraturen $i$ kort begreb, 1953, og F.J. Billeskov Jansens Verdenslitteratur, 1982. Alsidige og fyldige danske verdenslitteraturhistorier forfattet af udvalgte specialister er redigeret af Julius Clausen (I-III, 1897-1901), F.J. Billeskov Jansen, Hakon Stangerup og P.H. Traustedt (I-XII, 1971-74) og Hans Hertel (I-VII, 1985-93). I dansk særklasse er énmandsværket Verdenslitteraturen, I-III, 1928-29(-31) ved Niels Møller (1859-1941), som fylder intet mindre end 2.296 sider.

${ }^{2}$ Også en kirkehistorie og en filosofihistorie kunne uddrages af det fyldige bind, hvorimod en kunsthistorie og en musikhistorie kun ville bestå af få yderst tynde og spagfærdige passager.
} 
kan være meget andet end litterære data, fx regenters fødsel og død, tidsbestemmelser for krige og slag, lovgivning, regeringsskifter og lignende begivenheder i offentligt statsliv. Som det ses, ligger alle omfangsberegninger på litteraturhistorisk stof over $20 \%$, altså godt $1 / 5$ af det hele. Denne andel tåler en nærmere betragtning. ${ }^{3}$

Den ellers grundige udforskning af Grundtvigs 1812-krønike (Michelsen 1956, Aarnes 1961, Christensen 1998, Vind 1999) undersøger historiesynets tilblivelse og realisering og dets forhold til teologi, kirkehistorie og historiefilosofi, ofte udvidet til samtidens erkendelses- og modeltænkning. Men de litteraturhistoriske faktorer er ikke behandlet i deres indbyrdes sammenhæng. ${ }^{4}$

\section{Verdenslitteraturhistoriei Danmark før Grundtvig}

Den første bog trykt på dansk i Danmark er Rimkrøniken, 1495, en national kongehistorie i monologform, der går til og med Christian I's død i 1481. Hermed er trykkerifaget definitivt blevet bofast i riget. Efter Luthers lancering i Tyskland af sine 95 teser imod aflad i 1517 og de følgende års kritik af pavekirken samles næsten alle åndelige kræfter herhjemme om at bekæmpe eller fremme den reviderede religion. Den lutherske reformation sejrede politisk i 1536 og gennemføres ubegribeligt hurtigt juridisk.

Udgiveren Herman Weigere markerer derpå som den første i fortalen til sin omhyggelige og gennemkommenterede oversættelse til dansk af den nedertyske rævebog i 1555, at det nye bogtryksmedium også kan tage sig af rent verdslig digtning. Det fremkalder dog i perioden frem til praktisk talt 1700 ingen værker på dansk om udenlandsk litteratur på folkesprogene engelsk, tysk, fransk, spansk og italiensk, ej heller mange oversættelser fra disse nationale kulturer. I den lærde verden står de østerlandske sprog i gammel tid samt klassisk græsk og klassisk latin med deres tilhørende litteratur- og især sproghistorie i centrum. Oversættelser fra antik litteratur fremkommer, men også de er ret sjældne. Et kvalitativt gennembrud danner Birgitte Thotts danske Seneca-tekst trykt 1658, og ved samme tid præsenteres også flere europæiske modersmål med lærebøger og grammatikker beregnet på danske læsere. Forfatterleksika og bibliografier over danske skribenter skrives oftest på latin, og universitetsdisputatser afholdes og trykkes udelukkende på latin. Selv om sådanne tekster

\footnotetext{
${ }^{3}$ De litteraturhistoriske afsnit i $V K 1812$ er behandlet af Lundgreen-Nielsen 1980, 546-563. Grundtvigs ambitioner om at fremtræde som æstetiker, litteraturhistoriker og kritiker i årene 1804-26 fremgår af den kronologiske oversigt i LundgreenNielsen 1985, 114-116.

${ }^{4}$ En senere historiker dømmer, at Grundtvig i VK 1812 nok fordyber sig i "Samtidens eller de foregaaende Tiaars Aandshistorie", men at litteraturhistorien ikke "i videre Forstand angaar ham egentlig" (Møller 1950, 24).
} 
kan bringe litteraturhistoriske fakta og overvejelser, må de snarere opfattes som øvelsesstykker efter kodificerede internationale regler end som selvstændig forskning. Også litteraturtidender, der oplyser om litterære nyheder og anmeldelser af disse, gør det på latin. Men disse genrer danner dog en begyndelse til en hjemlig litteraturvidenskab.

Den lærde københavnske polyhistor Ole Borch (1626-90) afholdt i årene 1676-81 7 latinske disputatser om poesi, som tryktes enkeltvis i København og optryktes samlet fra Frankfurt a.M. i 1683 som bogen Dissertationes academicae de poetis. De omhandlede bl.a. italienske renæssancedigtere og franskmændene du Bartas med skabelsesdigtet Hexaëmeron, 1579, og Paul Scarron med Le Roman comique, 1651-57. I den 7. afhandling forekom Anders Arrebo, Søren Terkelsen, Anders Bording, Thomas Kingo, Henrik Gerner og Dorothea Engelbrechtsdatter. ${ }^{5}$ En dansksproget udgave af denne æstetiske akademikerforskning tænkte ingen på.

Daniel Georg Morhof (1639-91), professor poëseos i Kiel fra 1665, bragte i sit banebrydende standardværk Unterricht von der teutschen Sprache und Poesie, deren Uhrsprung, Fortsetzung und Lehrsätzen, 1682, fem indledende kapitler om italiensk, spansk, fransk, engelsk og nederlandsk versdigtning for at have noget at sammenligne tysk poesi med. Han kender Shakespeare af navn, men indrømmer åbent intet at have læst af ham. Skønt Morhof vist hverken forstår islandsk eller dansk, strejfer han faktisk gammelnordisk skjaldekunst og danske kæmpeviser, som han kan orientere sig om på latin i det videnskabelige apparat i Ole Worms skrifter om danske runer 1626-51, i Stephanus Stephanius' Saxo-udgave, 1644-45, og i P.H. Resens udgave af Snorres Edda, Völuspá og Hávamál, 1665. Peder Syv brugte ham ved redigeringen af sin 200-visebog i $1695 .{ }^{6}$

84 år senere blev verdenslitterære emner behandlet på tysk ved slesvigeren H.W. Gerstenberg (1737-1823) i Briefe über Merkwürdigkeiten der Literatur, 1766-67. Det gjaldt Shakespeare, Ossian og engelske folkeviser. Europæisk set indgår Gerstenberg i en forskerkreds, der i det 18. århundrede tæller kulturrelativisterne Montesquieu, P.-H. Mallet og J.G. Herder. De inddrager alle digtning, mytologi og kunst i sammenlignende skildringer af forskellige europæiske nationers åndelige stade.

\footnotetext{
${ }^{5}$ Paludan 1887, 456-457 (med citater fra Borch efter Rahbeks oversættelse i fortalen til hans og Rasmus Nyerups Den danske Digtekunst, IV, 1808).

${ }^{6}$ Et imponerende verdenslitteraturhistorisk udsyn åbenbares i forskellige udkast ved historikeren Hans Gram (1685-1748) til en fortale til den ældste samlede udgivelse af et dansk forfatterskab, Anders Bordings Poëtiske Skrifter, 1735. Disse forarbejder publiceredes dog først (med indledning og punktkommentarer) af Erik Sønderholm i 1984-85.
} 
På dansk opdyrkes dette felt i Ludvig Holbergs historieskrivning ${ }^{7}$ og spredt i hans Moralske Tanker, 1744, og i Epistler I-V, 1748-54. Tendensen fortsættes stilfærdigere i J.S. Sneedorffs tidsskrift Den Patriotiske Tilskuer, 1761-63. I Norge udsender P.F. Suhm under pseudonymet Philaletus (på græsk-latin 'sandhedens elsker') sine Tronhiemske Samlinger i 5 bind, 1761-65, med håndfast inddeling af europæisk litteratur fra ca. 1500 til samtiden i de "gode" og de "slette" bøger, fortrinsvis efter et kristent-moralsk dydskriterium; de enkelte notitser er i reglen kortfattede. Voltaires Jeanne d'Arc-epos La Pucelle d'Orleans, 1755, her dateret 1758, udløser en hvas dom: "Det er uvidst om enten Guds Bespottelse eller Liderlighed hersker mest i dette Skrift. Versene og Stilen ere og meget maadelige, og forsømte" (Suhm 1765, 300). Om den pseudonymt udsendte prosabog Candide, 1759, lyder det lige så vredt: "Voltaire skal have skrevet denne lumpne, liderlige og meget ilde skrevne Roman" (Suhm 1762, 135). ${ }^{9}$

I København fortsættes Sneedorffs og Suhms bestræbelser af Knud Lyne Rahbek (1760-1830) i diverse tidsskrifter fra og med 1785; også andre danske tidsskrifter bragte litteraturhistorisk stof. Den københavnske universitetsprofessor Jacob Baden (1735-1804) tager fra en sprogligstilistisk vinkel den danske samtidslitteratur op til drøftelse. En regulær dansk litteraturhistorie i 6 bind udsendes af Rahbek og Rasmus Nyerup i løbet af årene 1800-28, dog kun omfattende digtning på vers, altså med udelukkelse af Holbergs komedier og genrer som romaner og prosafortællinger.

Goethes berømte lancering mundtligt 31. januar 1827 af selve ordet "Weltliteratur" med påhæftet definition (jf. J.P. Eckermann: Gespräche mit Goethe, 1836) kunne Grundtvig selvsagt ikke forudse i 1812.

\footnotetext{
${ }^{7}$ Markantest nok i Dannemarks og Norges Beskrivelse, 1729, i Epistola III (den indlagte betænkning over nogle europæiske nationer), 1743, og i Herodiani Historie (den indledende afhandling "Om Aarsagen til Roms umaadelige Tilvæxt"), 1746. Hertil kommer Europa-oversigten i kap. XIII af Niels Kliim-romanen, på latin 1741, i dansk oversættelse 1742.

${ }^{8}$ I auktionskataloget fra 1873 over Grundtvigs efterladte bøger står Suhms pseudonyme tidsskrift som nr. 8954-58.

${ }^{9}$ Ifølge auktionskataloget fra 1873 over Grundtvigs efterladte bøger har han ikke ejet disse to titler af Voltaire. Han indrømmer i 1815 aldrig at have læst La Pucelle (1815b, 57), og det er uvist, om han nogensinde har læst Candide. I studieårene 1801-03 slugte han en "gyselig Mængde Romaner" (US I, 29), lånt i et københavnsk læsebibliotek. I maj 1804 gør han i sin dagbog op med såvel borgerlige som psykologiske og historiske romaner (Lundgreen-Nielsen 1980, 107-116). På Egeløkke fra ca. april 1805 udskiftede han definitivt kommerciel, men kunstnerisk jævn romanlitteratur med tysk romantisk filosofi og kildeskrifter fra det gamle Norden.
} 
Siden Morhof havde andre tyskere dog tidligere taget emnet op. Den professionelle europæiske genre verdenslitteraturhistorie er faktisk netop opstået lige før den tid, da Grundtvig inkluderer den i VK 1812. To professorer fra Göttingen går forrest, Friedrich Bouterwek (1766-1828) med pionerarbejdet Geschichte der Poesie und Beredsamkeit seit dem Ende des 13. Jahrhunderts, 1-12, 1801-19, ${ }^{10}$ og Johann Gottfried Eichhorn (1752-1827) med hovedværket Geschichte der Litteratur von ihrem Anfang bis auf die neuesten Zeiten, I-VI, 1805-12. ${ }^{11}$ I Grundtvigs studietid 1800-03 og hans år som tjenstledig cand. theol. 1803-05 forelæste Rasmus Nyerup i egenskab af universitetsbibliotekar ved Københavns Universitet over litterærhistorie, ud fra Eichhorns europæiske Litterärgeschichte, I, 1799 (Conrad 1996, 40, jf. auktionskataloget 1873, nr. 4782 $2^{12}$ ). Grundtvig synes ikke at have bemærket dette. I sit første brev (fra Egeløkke) til Nyerup af 1. maj 1807 kalder han sig "en Ubekendt" for denne (BG I, 5).

A.W. Schlegel holdt forelæsninger Über schöne Litteratur und Kunst (med universalhistorisk sigte) i Berlin 1801-04 og Wien 1808. Grundtvig har ejet hans Über dramatische Literatur und Kunst, 1809 (auktionskataloget 1873, nr. 8434-8436). Friedrich Schlegels forelæsninger over den nyere historie i Wien 1810, der udkom i 1811 (nr. 4950), nævnes af Grundtvig i VK 1812 som eksempel på naturfilosofiens "gode og slette Sider" (US II, 354). Desuden ytrede Friedrich Schlegel sig om verdenslitteratur i sit tidsskrift Das deutsche Museum 1812-13 og indbød i januar-februar 1812 Grundtvig til at skrive i det om sagaer, eddakvad eller allerhelst den endnu utrykte Beowulf-tekst ( $B G \mathrm{I}, 55-56)$, hvad der dog ikke blev noget af. Schlegels Wiener-forelæsninger fra 1811, der udkom som Geschichte der alten und neuen Literatur, 1815, kendte Grundtvig først i 1817 (Lundgreen-Nielsen 1980, 749 og 918).

\footnotetext{
${ }^{10}$ Friedrich Bouterwek var fra 1802 til sin død professor i filosofi ved det moderne humanistisk orienterede Georgia Augusta-universitet (åbnet 1737) i det britisk-hannoveranske Göttingen. Grundtvig har vist kun kendt til en bog på tysk om angelsaksisk bibelsk digtning fra 1849 ved hans nevø Karl Wilhelm Bouterwek (1809-68) (auktionskataloget 1873, nr. 4022).

${ }^{11}$ Eichhorn var orientalist og filosofiprofessor i Göttingen fra 1788 til sin død. Han nævnes kort som forskertype (i flertal!) i Grundtvigs VK 1817 (552, US III, 681), men nærmest negativt som en af dem, der i forlængelse af Herder beundrede poesien i Det Gamle Testamente uden at tage den for Guds ord. Et Grundtvig-manus fra 1825 typebestemmer Eichhorn på samme vis (Vind 1999, 552). Auktionskataloget over Grundtvigs bibliotek 1873 viser, at han har ejet skrifter udgivet før 1812 af Eichhorn (nr. 4774-4781, 4782, 4783-4785, 4952-4957 og 7820-7821) og A.W. Schlegel (nr. 8434-8436), men ikke, hvornår han har anskaffet dem.

${ }^{12}$ Titlen er i auktionskataloget angivet som Allgemeine Geschichte der Cultur und Litteratur des neueren Europa, 1799.
} 


\section{Grundtvigs greb om stoffet}

Grundtvig søger på forskellige måder at udvælge, styre og fremstille sit store verdenslitteraturhistoriske stof i $V K 1812$.

Korthed er det vigtigste krav. Der gives overordnede og fyndige karakteristikker, nogle få gange også litteraturtekniske kommentarer, men mest rappe og skrappe rids til indplacering i et universalhistorisk helhedsbillede. Vurderingerne af såvel personer som bøger fordeler sig på en skala fra dødelige kvæstelser til overdrevne udmærkelser. Klarhed er et andet krav. Grundtvig siger sin mening umisforståeligt - og det subjektivt mere end objektivt. Netop de summariske vota gør hans krønike til en livlig og livfuld præsentation.

Man kan beklage værkets savn af anskuelighed (Rønning 1909, II.2, 27-28), fordi Grundtvig hele tiden taler med og vurderer. En ultrakort undtagelse er dog hans skildring af massakren Bartholomæusnat 1572: "Om Nattetide blev Løsenet givet til denne Mørkhedens Idræt, Gaderne strømmede med Blod, Husene fyldtes med Lig og Luften med Hylen" (266, jf. VK 1817, 177).

Kun få litterære emner slipper uantastet fra Grundtvigs behandling, nogle gange endda nok takket være uvidenhed eller forceret hast. De blideste udsagn gælder Jason-sagnet og Iliaden og Odysseen (US II, 195), Juvenal (393), Nibelungenlied og Heldenbuch (233-234), Petrarca og Boccaccio for deres anbefaling af at læse antikkens grækere (240), engelske middelalderballader (260-261), spanieren Lope de Vega (270), de limousinske og kastilianske digtere, der "rørte først Harpen, naar de selv havde kæmpet i Marken" (269), og Salomon Gessner (328). En oprindeligt neutral omtale af Calderón (270) annulleres dog i Rettelser (398).

Der er enkelte blinde pletter i Grundtvigs verdenslitteraturhistorie. Den kristne digtning på angelsaksisk i England er slet ikke med, skønt Grundtvig véd om den allerede i 1808-09 (jf. NM 1808, US I, 326-327, og her note 52). Unævint under det franske 17. århundrede er jansenisten Pascal. Ved den fransk-orienterede svenskekonge Gustav III i det 18. århundrede forekommer navnet C.M. Bellman ikke. ${ }^{13}$ I Danmark tier Grundtvig ikke blot om H.A. Brorson, men også om Schack Staffeldt. Sidstnævntes Digte, 1804, er ellers den eneste skønlitterære bog på dansk fra det nye århundrede, Grundtvig ejer, da han 20. december 1805 gør sit privatbibliotek på Egeløkke op i et lille systematisk ordnet håndskrevet katalog (Fasc. 501.1). Staffeldts brændende erotik og hans antydninger af, hvorledes den kan håndteres, har formentlig været en væsentlig faktor i

${ }^{13}$ Den danske Bellman-begejstring kom først på fode med J.L. Heibergs vaudeviller i 1820'rne og dyrkedes af især ægteparret Heiberg og husvennen Henrik Hertz fra og med deres fælles Hørsholm-sommerferie 1832. 
Grundtvigs overlevelsesmanøvrer over for Constance Steensen Leth. Grundtvigs tid i København fra maj 1808 til lige før pinse 1811 er imidlertid uden nye forelskelser, og som forlovet med Lise Blicher fra og med september 1811 har han måske villet fortrænge Constance-årenes betagelse af Staffeldt. ${ }^{14}$

Bellman og Staffeldt kan være udeladt som definitivt ikke-kristne, Brorson, fordi Grundtvig endnu ikke var bekendt med hans salmer.

Modsat de fleste senere verdenslitteraturhistorier på dansk ${ }^{15}$ refererer Grundtvig ikke enkelte værker eller giver sig af med tekstnære tydninger af dem. Der er heller ikke nogen videre sammenligning (komparatisme) at spore, fx forsøg på at jagte påvirkninger eller slægtskab mellem teksterne som mønster, videreudvikling eller skræmmebillede. Digtning forstås som et udtryk for digterens inderste sjæl, enten bekendelse eller forkyndelse, og derpå kan dens artikuleringsmåder drøftes. Poeterne bedømmes ud fra kriterier, de ikke selv har sat. De indgår i et gruppebillede af tider og steder, bliver cifre i et regnestykke, opstillet af Grundtvig.

Åndens og kulturens alt for menneskelige rute med stationer af mere og mere ødelæggende art afslører Grundtvig ved at iagttage de bildende kunster. Først bevares "forstenede Billeder af hvad der livlig rørte sig i Oldefædrene og prægede sig i deres Idrætter [gerninger; praksis]" (US II, 344). Det svækkes for den næste slægt, som ikke "i Fædres Huse, men i Bøger og Konstsale" (museumsudstillinger? ${ }^{16}$ ) kan lære egenskaber som ærlighed, mod, trofasthed og fædrelandskærlighed at kende og dertil religionen selv. I det følgende slægtled vil selv "den afmalede Bedrift tykkes ubegribelig som en Mythe; igien skal en kraftløs, overtroisk Flok i Mandelignelse bøie Knæ for Farven og Stene, og hvad Digtere have siunget til Skemt [tidsfordriv] skal troes som Aabenbaring. Det er Europas Dom, hvis den længer forhærder sig mod Sandheden, kraftige Vildfarelser skal udskikkes og paa Løgn skal Man tro".

\footnotetext{
${ }^{14}$ I sin pure ungdom før 1805 havde Grundtvig dog slugt T.C. Bruuns dristige eller rent ud liderlige digte og følgelig i sin egen eddagendigtning "Freis Kærlighed" ladet titelpersonen drømme om at svøbe sig trindt om jættepigen Gerda (NM 1808, US I, 315). Det står der ikke i slutstrofen af det islandske Skírnismál (For Skirnis). Billedet er snarere en genklang fra Staffeldt, der i digtet "Under Lillas Vinduer" fra Digte, 1804, lader sin fantasi skue den yndige i sengens bølgende hynder og ser sig selv "i uopløseligt Favn / Vikle mig sammen med dig!" (Blicher 2001a, 418, v. 66-67, jf. også "Lillas Minde", 394, v. 326, og 397, v. 463-464). De danske guldalderdigtere udmærker sig ellers ved "en rolig Indecens" (Rubow 1958, 69).

${ }^{15}$ Den første af arten er Almindelig Literaturhistorie, 1876, oversat ved Fr. Winkel Horn fra Johs. Scherr: Allgemeine Geschichte der Literatur, I-II, 1851 (i talrige oplag), dog tilsat afsnit ved oversætteren med særlig hensyntagen til Norden.

${ }^{16}$ Netop i 1810 'erne bliver private fyrstelige kunstkamre og pinakoteker i Europa omdannet til offentlige museer (Sedlmayr 1948/1983, 31-33).
} 
Grundtvigs afgjorte kulturpessimisme anno 1812 er et ejendommeligt ungdomsfænomen hos ham. Som moden mand står han fra og med 1830'erne for en optimistisk vækstfilosofi på trods af ydre tegn til afvikling i stedet for udvikling. I og lige efter 1864 er Grundtvig nærmest den eneste danske digter af rang og ry, der forudser en oprejsning efter nederlaget og tabene i den græsselige krig.

\section{Sortering og organisering}

Med sin tætte brug af litteraturhistorisk stof bringer Grundtvig noget nyt og hidtil uset ind i dansk historieskrivning. Forbilledet kan umiddelbart have været Henrich Steffens. Den ældre fætters 7.-9. indledningsforelæsning op mod jul 1802 og hans dårligt besøgte, utrykte og måske ikkenedskrevne Goethe-forelæsninger i april-maj 1803 blev ikke omgående, men ved lidt senere eftertanke eksemplariske for Grundtvig. Før disse forelæsninger kendte Grundtvig slet ikke Shakespeare, Cervantes, Goethe, Tieck eller Novalis, siger han selv i 1838 (MM 1877, 275-276). Steffens havde sandsynligst samlet sit litteraturhistoriske stof op hos brødrene A.W. og Friedrich Schlegel, fx ved at læse bidrag i deres fælles tidsskrift Athenaeum, 1798-1800, eller i samtaler med dem. ${ }^{17}$

Hertil kommer Grundtvigs egen historieundervisning 1808-10 på Schouboes Institut, hvor han praktisk-pædagogisk delte oplysningen om hvert land (folk, nation) i tre afsnit: Geografi, Historie, Indvortes Forfatning. ${ }^{18}$ Det sidste kunne bl.a. være kultur og kunst.

VK 1812 bliver som verdenslitteraturhistorie på godt og ondt metodisk en forløber for Georg Brandes' litteratur- og åndshistoriske Hovedstrømninger $i$ det 19de Aarhundredes Litteratur i 6 bind, holdt og udgivet 1871-90. ${ }^{19}$ Dem stod der så stor blæst om, at de første 3 og mindst afbalancerede bind bar hovedskylden for, at Brandes ikke fik professoratet i æstetik ved Københavns Universitet efter Carsten Hauchs død i embedet i 1872. Stofligt sluttede Brandes sin forelæsningsrække i 1890 med skildringen af revolutionsåret 1848 og nåede således kun halvt igennem sit 19. århundrede. Grundtvig gik helt frem til udgivelsesåret 1812 med sine alt for oprigtige portrætteringer af samtiden og forudså endog en art genfødelse fra Norge af noget værdifuldt i 1813. Det fik i 1816-17 de daværende historieprofessorer i København til at holde ham ude fra universitetet med det $\mathrm{i}$ og for sig rigtige argument, at han endnu ikke syntes at være afklaret som fagmand (Lundgreen-Nielsen 1980, 678 og 757).

\footnotetext{
${ }^{17}$ Paul 1973, 191, 192, 204-206: Steffens var personligt bekendt med Goethe, A.W. og Friedrich Schlegel, Fr. Schelling og Novalis.

${ }^{18}$ Michelsen 1956, 43.

${ }^{19}$ Oprindeligt skulle titlen have været Grundstrømninger (Brandes 1907, 62).
} 


\section{Praktisk værktøj}

Gennemgående kontante greb - og overgreb - gør Grundtvigs opgave håndterlig.

Han inddeler resolut nationer og folkeslag $\mathrm{i}$ de gode og de slette og dømmer dem konsekvent herefter. Gode folk er de antikke grækere, tyskerne, danskerne (medregnet nordmændene) og spanierne. Slette folk er med årsagerne i parentes - de antikke fønikiere (købmænd), de gamle ægyptere (dyrisk og legemlig religion), de antikke romere og de senere italienere (materialister og vellystninge), englænderne (med bispelig kirke og udbredt uterlig litteratur, dog fraregnet Spenser og Shakespeare; venligere behandles skotter ${ }^{20}$ og irere), svenskerne (håbløst bagefter i udvikling, sen rigssamling, trofaste tilhængere af fransk kultur), hollænderne (tunge og legemlige) og franskmændene (snilde og selvkloge, uden respekt for Gud eller konger, lystigt levende). Franskhedens kulmination er Voltaire, som kun omtales negativt. Hans tolerance-begreb har den unge Grundtvig ikke sans for.

Grundtvig kendte i Europa intet til slaviske folk og deres sprog og litteratur og lod dem ligge.

I fortalen til VK 1812 omtaler Grundtvig jødernes historiske og nutidige rolle som "denne sande Jerusalems Skomager, der aldrig kan dø, men maa vanke Verden om i Foragt og vidne om Kristus, til Han kommer" (US II, 183). Både Det Gamle og Det Nye Testamentes jøder ville han gerne have skildret, men fandt ikke for sig "en nogenlunde fuldstændig Udsigt over Folkets aandelige Idræt [bedrifter], og de to adskillige [forskelligartede] Slægters Vandring”. Denne defekt i Grundtvigs viden skyldes efter hans egen mening, at han fra 1811 som kapellan for sin alderdomssvækkede fader var bundet til Udby uden adgang til lærde biblioteker. Disse hindringer er dog i hans optik ikke nye, for i 1800 år har Det Gamle Testamentes profetskoler ikke mødt "den for Geniet nødvendige Opmuntring, det er Bifald, Skænk og Hæder", og selv "vor oplyste Tid” har endnu ikke "opfundet den rare [sjoeldne] Konst at optugte eller opkæle Folk til Poeter". Altså savnede fårehyrden David både lærdom og opmuntring, ${ }^{21} \mathrm{og}$ profeterne fik kun "maadelig Brageløn". Det er måske et forsigtigt selvportræt.

De andre verdensdele skulle have stået for sig til sidst, men det blev ikke til noget, hvad der var "ei saa liden en Feil". Men alligevel overdænger Grundtvig dem med afstandtagende betegnelser: "Indien med sit døde Sanskrit og sine visne Braminer", "Oldingen Kina, der af Jordkræft fik en sørgelig Helsot [dødelig sygdom]", "Mahomeds nedgaaende

\footnotetext{
${ }^{20}$ I pjecen Europa, Frankrig og Napoleon, 1815, indrømmer Grundtvig dog om skotterne, at "jeg forstaaer ikke det Folk, jeg kiender det og ikke" $(1815 b, 122)$.

${ }^{21}$ Salmisten David nævnes 6 gange i VK 1812 som eksempel på den skæbne, lødig digtning får til forskellige tider (US II, 183, 211, 255, 275, 284, 315).
} 
Maane", "Nordamerika med dets Aviser og aandelige gule Feber", Sydamerikas "underlige Fødselsveer" og endelig Domingos [den senere dominikanske republiks] "Negerspir" pegende til Afrika.

Når et behandlet folkeslag omfatter "flere sammensmeltede Stammer, da kan det forene flere Evner i sig end ellers" (357), og stammerne kan have hver deres "særegne Gang" og "vexelvis oplive hinanden, hvorved den almindelige Fordærvelse og Undergang forhales". Sådan var det altid i Europa (men ikke i Asien eller Afrika), og det er kristendommens fortjeneste, at "aandelig Trældom er uforenelig med den i alle Maader". Grundtvig tilføjer, at disse sætninger langtfra kan udvikles af ham her, men må haves $\mathrm{i}$ tanker og udsiges, især når man vil forstå Nordens historie: "Endnu kan kun Opmærksomhed vækkes og enkelte Vink gives" (358).

Altså karakteriserer Grundtvig gennemgående både de udenlandske og de danske førende skribenter ved deres føde- eller hjemegn. Det er hans håb, at dette vil blive taget op i en fremtidig dansk historieskrivning. Han anskuer sine danske landsmænd som jyder, fynboer, falstringer, lollikker og sjællændere, de norske som guldbrandsdøler, trønder og halejer. Holstenere og saksere kommer også med, mens nabofolkene slaver og vender nærmest er åndløse. "Paa Folkenes Herkomst bero deres aandelige Evner mest, ligesom deres legemlige Skikkelse". Det kniber dog for Grundtvig med at få noget videre brugeligt ud af de forskellige danskeres psyker. ${ }^{22}$ Hans model passer måske bedre til politisk splittede folkeslag forenet af et mere eller mindre fælles tale- og skriftsprog, fx tyskere og italienere, end til just danskere. Grundtvig indrømmer selv, at alt dette er "almindelige Bemærkninger" (359), han kunne have lyst til at forøge. ${ }^{23}$

En vigtig formel er modsigelsen mellem hjerte (troens sæde) og hoved (forstanden, der vil frigøres). Den er fx aktuel vedrørende indsamling og offentliggørelse af historiske dokumenter ved udgiverforeninger, hvis indsats Grundtvig nedvurderer. I sin ungdom brød han sig heller ikke om museer med lærde arkæologer og uforstående besøgere, fordi de første var åndeligt blinde, mens de sidste blot kastede matte og nysgerrige blikke på

\footnotetext{
${ }^{22}$ Grundtvigs synspunkter i dette anliggende gøres (for) kort af i Michelsen 1956, 242-243. I Krønikens Gienmoele, svarpjecen til Molbech af 8. juli 1813, er Grundtvig stadig vag i sin forestilling om et føde- eller hjemstedskriterium: "Det synes nemlig mig at hver Provinds har en egen Characteer, en egen aandelig Synsmaade, og de af Provindsen der fremtræde som Skribentere og høres med Bifald, kalder jeg dens Fuldmægtige, fordi de udsige hvad de fleste mene, ere altsaa som deres Mund, og staae i Historien som Fuldmægtige (Repræsentanter) for alle deres tause aandelige Frænder" (68).

${ }^{23}$ I sine Rettelser til den allertidligste historie betoner Grundtvig dog, at "Forskellen mellem Noahs Efterkommere maa naturligvis ikke tages strængt, da Talen blot er om Stammernes Hovedstemning" (US II, 391).
} 
de udstillede genstande. ${ }^{24}$ En anden modsigelsesmetafor sætter ægte naturfødt kraft over for det, der er glattet og slikket indtil det kraftløse. Det er fra 1805 Grundtvigs vante holdning til den såkaldte skønhed i romansk inspireret nyklassicisme, både i digtning og i de bildende kunster. Skitser var liv, færdige værker død. ${ }^{25}$

Både ved perioder og enkeltpersoner griber Grundtvig til billeder af tilblivelse og af sygdom, forværring, kraftløshed, død og jordefærd efterfulgt af ligsange. Tilsyneladende sund kultur degenererer snart $\mathrm{i}$ overdådighed, luksus, misbrug og fører til råddenskab og opløsning. Enkelte værdifulde eller indflydelsesrige personer opviser en kort ungdomsblomstring fulgt af langsom og uafvendelig degeneration af talent og praktisk virke eller tomme og lidet overraskende gentagelser. En biologisk banalitet, kunne man mene, som Grundtvig demonstrerer for så mange af sine personer, at det ligner en naturlov. Den skulle han da for resten selv dementere $\mathrm{i}-$ og ved - sit eget liv.

Sin teori om verdsligt forfald belyser Grundtvig ud fra en generel sociologisk modsætning allerede hos oldtidsfolkene mellem verdsligtmaterialistiske bysamfund (inklusive jordbrug og minedrift) og et åndsbåret naturnært nomadeliv som hyrder i det frie. Byliv fremmer egoisme, ejendomsret og forbrydelser, mens hyrder i deres landliv med fritgående kvæg får alt af naturen og lader den derfor i fred i en sand fornemmelse af Guds nærvær. Nomadekultur kan rent ud symbolisere, at den jordiske tilværelse kun er en pilgrimsfærd med Himlen som mål. Bibelsk udtrykt er Abel og efter drabet på ham broderen Set og hans æt værdifuldere end Kains efterkommere (jf. US II, 188).

Helt overordnet bruger Grundtvig omkring en snes billeder med Strøm, Strømhvirvler, Bølgegang. Anskuelsen af historiens forløb som en strøm kan findes i Grundtvigs lyrik lige før 1812. Det er en bæk i "Odin og Saga" i samlingen Idunna, 1810, og vekslende bølger i "Havet" og småbølger i "Strandbakken ved Egeløkke", begge fra samlingen Saga, $1811 .{ }^{26}$ Grundtvigs øvrige billedsprog i VK 1812 omfatter hen

\footnotetext{
${ }^{24}$ Lundgreen-Nielsen 2010, 257-267.

${ }^{25}$ Det ses i den dengang utrykte dagbogsafhandling "Hvad er Poesi?" fra september 1805 (US I, 77-84, Albeck 1979, I, 218-226) og især i den uoptrykte afhandling "Om Schiller og Bruden fra Messina", skrevet i 1806 og trykt i Ny Minerva, juni 1807, spec. 229-234 om sondringen mellem "Konst" som harmonisk verdslig skønhed og "Poesi”" som længsel og stræben imod det Himmelske og Evige (jf. Lundgreen-Nielsen 1980, 152-159 og 168-173).

${ }^{26}$ I 1829 udsendte Grundtvig en lille undervisningsbog, Historisk Børne-Laerdom, sammen med et selvtegnet landkort (lånt hos tyskeren Fr. Strass, jf. SJ I, 44) betitlet Tidens Strøm eller universalhistorisk Omrids (med genoptryk 1832, 1843,1851 og 1870). Rigers og nationers historie fik her form af strømme med forskellig farve.
} 
ved 500 verdslige metaforer, hvoraf halvdelen er taget fra naturen. ${ }^{27}$ Den gennemgående tendens er, at organisk natur benyttes om positive historiske sammenhænge og uorganisk om negative.

Trods mulige ukendte hjælperedskaber er det forbløffende, hvor mange enkelte korte bemærkninger fra Grundtvig til selv mindre navne i verdenslitteraturen der rammer præcist - endog sammenholdt med moderne leksika og håndbøger. De kan være ensidige, men er ikke helt ved siden af. ${ }^{28}$ Det gælder også viden om de romanske litteraturer, som han næppe i 1812 havde nogen udstrakt læsning i. ${ }^{29}$

En systematisk undersøgelse af Grundtvigs litteraturhistoriske kilder savnes. ${ }^{30}$ Sidst i sin fortale beskriver han ganske kort sin læsning af middelalderhistorier ved A.H.C. Heeren, Johs. v. Müller, G.Fr. Creuzer og Simonde de Sismondi, men udpeger dog Gud som sin "ypperste Læremester" i historikerfaget (US II, 184-185, jf. også 29-31 om et fragment fra 1810 samt Michelsen 1956, 144-161). ${ }^{31}$ Grundtvigs benyttelse af Universitetsbiblioteket og Det Kongelige Bibliotek kan ikke eftergås præcist. ${ }^{32}$ Hvad han har læst og drøftet med sine bofæller på Valkendorfs Kollegium, unddrager sig kontrol. Personligt kendskab til alt det karakteriserede turde være usandsynligt.

${ }^{27}$ Materialet er fremlagt i Lundgreen-Nielsen 1980, 559-562.

${ }^{28}$ I svaret til Molbech, Krønikens Gienmcele, 1813, forsvarer Grundtvig kun to af sine litteraturhistoriske karakteristikker, nemlig af de nulevende kritikere Steffens og Rahbek (52-55, 85-87), som begge var ham personligt bekendte.

${ }^{29}$ H.A. Kofods danske udgave $1816-28$ af det nye tyske Brockhaus-leksikon 1796-1811 kan Grundtvig jo ikke have benyttet i 1812. Han læste tysk, men havde han mon adgang til dette opslagsværk i Udby-årene 1811-12?

30 25. januar 1812 hjemlånte Grundtvig fra Det Kongelige Bibliotek Daniel Jenisch: Geist und Character des achtzehnten Jahrhunderts, I-II, 1800 (bind III ejede biblioteket ikke). Men dels omhandler dette værk kun det 18. århundrede, dels er det efter forfatterens eget udsagn stærkt inspireret af Pierre Bayles Dictionnaire historique et critique, 1695-97, hvis religionskritik næppe kan have bekommet Grundtvig vel (Lundgreen-Nielsen 1980, 516). Ved sin død ejede Grundtvig Odin Wolffs biografiske leksikon Historisk Ordbog, I-XI, 1807-19 (auktionskataloget 1873, nr. 4529-4539), men det er uvist, hvornår han anskaffede det.

31 Jens Møller har i sin (anonyme) faglige anmeldelse af $V K 1812$ bemærket, at Grundtvig aldrig bruger ordet 'Historie' i sin fremstilling (DLT 1813, 405), hvad der næsten holder stik, såfremt man fraregner fortalen og indirekte citater af andres udsagn - men også kun næsten.

32 Det Kongelige Bibliotek åbnede for almindeligt udlån til offentligheden i 1793; den ældste kendte protokol herover er fra 1803. Universitetsbibliotekets udlånsprotokoller er først bevaret fra så sen tid, at det blotte efternavn Grundtvig kan gå på en af hans sønner (Toldberg 1946, 38). 


\section{Grundtvigs litteraturhistoriske længdeløb}

Grundtvigs kronologisk organiserede kortlægning af verdenslitteraturen skal nu følges i en refererende og citerende redegørelse med påsatte sidehenvisninger og nogle gange også med moderne kommentarer.

Den første litterat, Grundtvig nævner, er den hellige mand Moses, der for over 3000 år siden i Bibelen har "samlet de gamle Sagn om Verdens Oprindelse og de første Mennesker" (US II, 187), altså Det Gamle Testamentes 1. Mosebog. Af den fremgår det, at sprog og digtning ikke er et gudskabt levn fra Paradis-tiden, men at det var brodermorderen Kains desværre uterlige og fordærvede efterkommere, der i en bestræbelse for "at leve saa glade paa Jorden, som muligt" opfandt instrumentalmusik og mundtlig digtekunst, "Strengeleg og det velklingende Vers" (188). ${ }^{33}$ De dyrkede jorden, smedede malm og "byggede Stæder", blev bofaste, hævdede ejendomsret og gjorde for resten alle kun, hvad de lystede. Deres levevis var verdslig-sanselig og materialistisk. Det lyder særdeles negativt.

Grundtvig er nødt til at medgive, at allerede oldtidsfolkene dog kunne udvise en vis tillid over for digtere. En digter er for ham et menneske, "som Gud har forlenet et klarere Øie end Andre, til at opdage det guddommelige Spor, samt Evne til at meddele sine Syner i et henrivende, velklingende Sprog. Han henrives selv paa underlige [uforklarligt mirakuløse] Maader, naar han digter; det er for ham selv, som om han lyttede til Guds Stemme i sig, og meget mere maatte da Folkene tro, at høre Guds Røst igiennem ham" (190). Gamle halvglemte sagn iklædes en skøn "Billedkjortel" og frelses derved fra undergang, men risikerer at blive forfalsket og misforstået "end mere i de følgende Tider".

Grundtvig fastholder således sin skepsis over for litteraturens, musikkens og kunstens oprindeligste udøvere såvel som over for deres publikum. ${ }^{34}$ En senere adresse får alle disse parter i byer fyldt med ondskab

${ }^{33}$ Bibelen beskriver tilblivelsen af harpe- og fløjtemusik (1 Mos 4,21), men digtning nævnes kun direkte i VK 1812. I VK 1814 skriver Grundtvig, at Kains efterkommere (i Kina!) "fandt paa Strængeleg og Teltmagerie og Smedeværk af skarpe Vaaben" (27, efter 1 Mos 4,20-22), og i VK 1817 hedder det, at de "smeddede Malm og byggede Stæder, og opfandt Strengeleg og anden Kunst" (3). I Haandbog $i$ Verdens-Historien, I, 1833, reducerer Grundtvig denne tidlige kunsthistorie til det mere abstrakte udtryk "allehaande Strcengeleg" (US VI, 48) og udleder deraf, at et almindeligt håndværk som "Spille-Mandens" (49) er lige så gammelt som menneskeslægten selv.

${ }^{34}$ De klassiske atheniensere må således høre for, at de falder for "lave Konstgreb" (US II, 201). Andre publikumsfjendske steder står sammesteds på siderne 192, 194, 201, 212, 234, 239, 284, 320, 324-325, 327, 344, 355, 356, 362-363, 366-367, $373,374,379,384,396$ og 399. Det er typisk for den tidlige danske romantik, at den ikke vil anerkende publikums og litteraturkritikkens autoritet, hverken i ældre tider eller i nutiden. 
som Babel og Ninive. Grundtvig har i 1809 i en utrykt indledning til sit verdenshistoriske kursus på Schouboes Institut, som kun kendes fra en nedskrift ved en elev (Fasc. 215), fremhævet poesiens betydning for (sagn)historien: det er
denne herlige Gave Gud skænkede Jorden, som Vi have at takke for at dels saamange mærkelige [bemcerkelsesvcerdige] Sagn ere bevarede fra Undergang, og dels at de ere komne mere ufordærvede til Os, end det ellers vilde have været Tilfældet. Grunden hertil ligger deri at Poesien selv for det raaeste Menneske har noget Tillokkende, som uden at Han ved hvad det er, dog uimodstaaelig trækker ham til sig; ti heraf fulgte at Man ei glemte hvad der saaledes var besunget, og at Efterretningerne ei let kunde forfalskes, da Man straks mærkede paa Verset naar noget Betydeligt var taget fra eller lagt til, og holdt formeget af et saadant Digt til at taale at det blev forfalsket. Exempler ere de homeriske og ossianske Digte (Michelsen 1956, 48). ${ }^{35}$

Forrest i sine Rettelser vedgår Grundtvig, at han i VK 1812's første tidsrum ikke skelner "synlig" mellem Bibelens udsagn og sine egne ræsonnementer over dem (US II, 390). Han forsikrer videre, at de hellige profeter var mere end "blotte Digtere" (392). Men det er for ham utvivlsomt, at de ældste efterretninger om menneskeslægten via Moses bygger på "Ebræernes gamle Sange" (Michelsen 1956, 48). Og Abel-broderen Sets efterkommere førte et uskyldigt hyrdeliv under åben himmel, forgreb sig ikke på naturens rigdomme og kendte ikke til ejendomsret, var med andre ord nomader uden forventning eller krav om en bekvem tilværelse. Behersket af "gudfrygtig Enfoldighed" (US II, 191) følte de sig som gæster eller fremmede på Jorden, der først "bag Graven" skulle nå deres fædreland.

De gamle ægyptere manglede både digtekunst og sans for strengeleg. Resultatet er pyramiderne, "uhyre Stenbygninger" rejst ved legemsstyrke og målekunst, men blottet for "aandig Skønhed og Storhed" (194). Hos fønikierne herskede såvel verdslig pragt og overdådighed som dristighed til at rejse langt under hidtil ukendte himmelstrøg, men "ingen Digter lod sin Stemme høre" (192) hos "disse jordisksindede Kiøbmænd", og deres skriftsprog anvendtes kun til regnskaber.

Homers "deilige Sange" (196) om Achilles og Odysseus har bevaret disse heltes ry i tre årtusinder, men er blevet til "paa Lilleasiens Kyst", ikke i det europæiske Grækenland. Også grækernes digtekunst begyndte at hylde vellyst, overdåd og misbrug, så herlige poetiske evner måtte "lovsynge og forgude det Jordiske". Spartas magtherredømme udryddede "Hjertets helligste Følelser" (197). Athenienserne blev "driftige Sømænd,

${ }^{35}$ Michelsens tekstgengivelse er efterset i Fasc. 215 med et par smårettelser til følge. Michelsen ser i dette udsagn fra 1809 "en karakteristisk fremhævelse af den mundtlige traditions værdi" (48). Det er dog måske snarere et forsvar for versform som et godt hjælpemiddel til at bevare sagn og gamle efterretninger. 
Mestere i alle de bekendte Konster, Videnskabernes Fosterfædre og Smagens Dommere", og i alliance med spartanerne jog de perserne ud af landet. Endelig udbrød der krig mellem bystaterne Athen og Sparta, som sidstnævnte vandt. Men mindet om Athens 80 år som ledende bystat stod fast 2000 år efter på grund af kulturen. Digteren Æschylos vandt en "uforvisnelig Krands" (199) ved at skrive dramatik, der opførtes som skuespil, og derved fremkaldtes mennesker med "Anlæg til at efterligne Andre", som "talede og handlede i de Hedenfarnes Navn", altså skuespillere. At "beskue de oplivede Skygger af store Mænd" kan for publikum være "saare skikket til at vække en ædel Higen efter at ligne dem, og opløfte Sindet over det Legemlige". Dette er noget af det venligste, Grundtvig i sit liv har sagt om skuespillerkunst, som han ellers foragtede af et ærligt hjerte. Dramatikerne Sophokles og Euripides fulgte efter, med en mere udspekuleret komposition ("i kunstig Sammensætning"), men et ringere kvantum af "Kraft og ophøiede Følelser" (200). Aristofanes' komedier prisgav tidens latterligheder og dermed en del af medborgerne, men "Spot er en ond Urt [et ukrudt], som kun vokser paa Kærligheds Grav", diagnosticerer Grundtvig. En degenererende udvikling i retning af ideel jordisk skønhed sås hos Phidias og andre billedhuggere, for det er kun i en tid med sjælden og lunken tro, at "den usynlige Guddom" må vige for "synlige Billeder", der enten står "til blot Øienslyst" eller lokker til "det groveste Afguderi". Herodot, "Historiens Fader", samlede "med opmærksomt Øre" sagn rundt i landene og gengav dem "paa ukonstlet og trohjertig Maade, og tillagde da sit Skøn om hvad ham tyktes rimeligst at være", men han så dog en usynlig styrende "Finger" i det hele. Efter ham forstod den nøgterne historiker Thucydides alle udviklinger og omskiftelser i tidernes løb som resultater af menneskelig intelligens ("Virkninger af Mandevid") og endte med at sammensætte en indviklet og næsten uforståelig fortælling. Filosofferne Sokrates og Platon bekendte, at de intet vidste om det usynlige og satte sjælen over legemet, men den uinteresserede mængde ville hellere følge sine egne jordiske lyster. Det atheniensiske publikum accepterede kun digtning og kunstværker "for at more sig, ei for at opløftes" (201). Kun én gæv mand, taleren Demostenes, blændedes hverken af guld eller omtågedes af "Smigerdunsten" (202). Aristoteles savnes her, fordi Grundtvig gemmer ham til sin behandling af Lessing.

På inspiration fra sådanne grækere blev denne tendens endnu tydeligere i det antikke Rom, enten ved rene efterligninger (hos komediedigterne Plautus og Terents) eller ved "glimrende men kolde Lignelser, forstandige Sentenser og Vittighed, og hvor der er nogen Varme, er det næsten altid Skildringen af sandselige Glæder" (hos Vergil, Horats og Ovid) (208209). ${ }^{36}$ Dette pindes mere ud i Grundtvigs Rettelser, hvor romernes

\footnotetext{
${ }^{36}$ Ordet "glimrende" bruges af Grundtvig negativt om det, der skinner iøjnefaldende, men reelt kun er "Glimmer" (jf. US II, 178), altså et overfladefænomen uden
} 
heltekvad kaldes for jordisksindede gennemforstandige opdigtelser, misbrugt i "verdslige Øiemed" (392), og selv Vergils storladne nationalepos Aneiden tages med i denne gruppe. ${ }^{37}$ Tilsvarende blev mange billedstøtter slæbt til verdensbyen Rom, men "i det høieste til Øienslyst" (209).

De levninger af sand religion, der "i den ældre Tid havde oplivet og størket Folkene, vare begravede i en Dynge af Fabler og Eventyr". Slægten måtte henrådne under den bogstavelige kejsertilbedelse, såfremt en ægtere tro ikke kunne vækkes til at tæmme de syndige lyster, men "den senere Tids Digtere vare ofte Gudsforagtere, fordybede sig selv i Jordlivet og misbrugte deres Kunst til at forgylde Lasten, eller til, ved Smiger at vinde de Mægtiges Yndest". Og det, skønt digterne var "de eneste, Man kunde tiltroe et Samfund [follesskab; forening] med Guddommen, som gjorde deres Udsagn om det Usynlige troværdig" (210).

Her følger så et afsnit om israelitternes eller jødernes historie og kultur. Det hedder om David, at han for "at vække den slumrende Andagt og ligesom laane den Vinger til Himmelflugt" (211) indførte strengeleg ved gudstjenesten og "digtede dertil selv hellige Sange, der ei blot ere beundringsværdige formedelst deres poetiske Fylde og høie Sving, men især dyrebare ved den Trøst de som Himmeltoner mægte at indgyde et bedrøvet Hjerte, og formedelst det Fremsyn ind i de kommende Tider, som bekræfter Digterens underfulde Samfund med Gud" (211-212). ${ }^{38}$ Profeter opstår som "hellige Digtere" (212).

De romerske digtere under den kloge Augustus bar blomster uden frø, hvoraf nye kunne spire. "Dette uhyre Rige stod som et udgaaet Træ med store, visne Grene, hvor sjelden en Fugl bygger Rede eller rører Stemmen, men hvor kun Utøi avles og næres i det raadne Trøske, medens giftige Orme bo i den hule Stamme" (216). Nok hedder perioden en guldalder, men det er for Grundtvig at tage aftensolens skær, der bebuder nat, for morgenrøde. Egentlig er Grundtvigs billede af det romerske træ vel en parodi på nordisk mytologis verdensask Yggdrasill. ${ }^{39}$ Parallelt med det anfører Grundtvig, at i Norden "forfalskedes" de gammelnordiske sagn "daglig" af

ægte lys eller ditto varme, et falsk signal. Denne betydning har ordet overalt i $V K$ 1812. Det angiver ikke som på nudansk, at noget er 'godt', 'udmærket' eller 'fremragende'.

37 Allerede i Schouboe-undervisningen i 1809 frakendte Grundtvig kejsertidens poeter ægte digteriske egenskaber og føjede til, at disse beundrede navne endda sjældent var romere, men stammede fra byen Roms nabofolk i Italien (Michelsen 1956, 63 og 143).

${ }^{38}$ I $V K 1812$ nævnes verdenslitteraturens salmedigtning kun et dusin gange (US II, 211, 254-255, 275, 284, 293, 299, 302, 315, 370, 374, 381, 389).

${ }^{39}$ Eller en vrangvending af Olaf Tryggvesøns storstilede programtale om kristendommens banner som et træ, der skal beskytte hele Norge, fra akt 3 i Oehlenschlägers sørgespil Hakon Jarl hin Rige, 1807. 
de islandske skjaldes udsmykninger (dvs. kenninger og heiti ${ }^{40}$ ) (221). I Rettelser indføres her en omtale af satirikeren Juvenal og samleren Plinius - uden karakteristikker - og det fortsætter i et længere angreb på forskere, der mener, at Daniels profetier om et romerrige er senere digtninger om de begivenheder, profeten forudså, for "hvorledes skulde Spaadommene være forfattede, efterat de Ting vare skedte, som ei kunde ske uden formedelst dem?" (394). Og, spørger Grundtvig videre, hvilke poeter har man efter udfrielsen af det babylonske fængsel? Hos "Sirach lære vi, hvad som da kaldes Poesi, nemlig sligt høitravende Billedsprog, som ogsaa vi have givet dette Navn; men hvilken uhyre Forskel mellem det og de gamle Profeters Qvad". Han slutter hovedrystende: "Dog, naar man lukker Øinene, nytter det ikke at Lyset skinner klart, det er alt hvad Man kan sige. - - "41

Middelalderen med korstog og ridderlige idealer gøres meget hurtigt af. Den handler "mest om Kærlighed (...) og om anden Dyd" (233) (Richard Løvehjerte og Saladin), "stundom og om Himlen og dens Konge". I sine Rettelser mener Grundtvig dog, at han har malet pilgrims- og korstogstiden med alt for lyse farver, til dels på grund af "det saa saare Poetiske der udmærker den" (395), altså en stræben efter det himmelske og evigheden. Mange korsfarere havde nok andre motiver og troede kun slet "paa Kristi Forsoning og Guddom", når de ville lede efter ham i hans grav. En afbalanceret fremstilling vil alene kunne gives $i$ "en Udvikling, hvor Gerninger tale og danne $\mathrm{i}$ den Opmærksommes Sjæl et Billede, hvis Farveblanding kun kan beskues, ikke beskrives. - - ". Desværre savnes en stor fremstilling af korstogene, der ellers ville have fået det trojanske (og mindre betydende) tog til at miste glansen, fordi "Det Vidunderlige (...) er virkelig og saa øiensynligt". ${ }^{42}$ Her bruger Grundtvig på dansk begrebet le merveilleux fra fransk klassicistisk poetik (samt fra Holbergs Peder Paars, 1719-20). Rettelser indføjer en nedsættende bemærkning om epikeren Tasso, som "af Mangel paa Sandhedskærlighed og Syn for det virkelig Store udstafferede [overpyntede] Korstoget, som Han vel mente at forskønne". Tassos beretning om den danske prins Svend Korsfarer kan Grundtvig "ei rigtig" hjemle historisk, og den burde måske være udeladt. ${ }^{43}$

\footnotetext{
${ }^{40}$ Henholdsvis gådeagtige omskrivninger, fx kampens ild = sværd, og faste synonymer for visse substantiver (inkl. egennavne), således havde Odin, guden for både krig og poesi, hele 169 forskellige heiti, fx Fjolnir. Disse to stilfigurer kendes fra skjaldepoesi og findes ikke i norrøn prosa.

${ }^{41}$ Jf. Es 6,9-10, Matt 13,15 og Paulus i ApG 28,27.

${ }^{42}$ I sensommeren 1810 havde Grundtvig forsøgt at skrive en digtkreds om korstogene (Lundgreen-Nielsen 1980, 350-351, 368-369), men opgivet den.

${ }^{43}$ Torquato Tasso (1544-95) indsætter denne danske prins i 8 . sang af sit store epos Gerusalemme liberata, 1581. Nyere danske opslagsværker identificerer ham som kong Svend Estridsens søn, der på sin vej til Jerusalem under det 1. korstog skal være faldet i Anatolien i 1097.
} 
Rettelser har også et indskud om de italienske bystaters kunst og poesi omkring 1200: de repræsenterer "det samme tøileløse Begreb om Frihed, samme Hang til Leg med det Aandelige, og til at formæle det med det Sandselige" (396) som i det antikke Grækenland. Dette dadler Grundtvig senere i sin hovedtekst Goethe og Oehlenschläger for.

Mest bemærkelsesværdige i den kontinentale middelalder er de omfattende tyske kvad Nibelungenlied og Heldenbuch, "hvor gamle Hændelser ere blandede med de nyere Tog mod de Vantroe og besjungne tilhobe [sammen; under ét]" (234). Dertil kommer opkvikkende skæmtesagaer (dvs. underholdning og tidsfordriv) om fortids- og samtidshelte $i$ "Romaner", en art digte fra Normandiet, som ikke er ægte historiske, men "til desstørre Forlystelse ere udsmykkede langt over det de vare i Sandhed". Altså ikke historie, men historier.

Intetsteds var denne menneskeånd dog så "hæderlig" [glorvordigt] på færde som i det høje Norden med de islandske "liflige Kvad" om guder og helte og "deilige Skæmtesagaer", alle "uvurderlige Skatte" til eftertiden sammen med Valdemarernes snilde lovbøger, Saxos Danmarkskrønike "paa fint og kosteligt Latin", Snorres så godt som mageløse Norgeshistorie (Heimskringla) og det islandske Kongespejl.

I Sydeuropa har vi konkurrencen mellem de italienske bystater, som i Firenze avler de "tvende Mesterskjalde Dante og Petrark" (239) (hvis digtning Grundtvig dog slet ikke kommer ind på). ${ }^{44}$ Men ugudelighed og egennytte fortrængte snart gudsfrygt og fædrelandskærlighed i Firenze, så byen til skade for borgerne beherskedes af de rige købmænd fra det Mediceiske hus. Petrarca og Boccaccio anbefalede studier af de antikke skrifter og kendskab til græsk sprog, og nogenlunde samtidig opstod europæiske "Samfund [foreninger] af lærde Mænd" under navn af universiteter (240).

Bogtrykkerkunstens opfindelse skildrer Grundtvig vist i et Kristusbillede: den er "hemmelig i sit Udspring som alt det Herlige Jorden saae, ringeagtet som det i sin Barndom, men i sin Ungdom Lysets ubetvingelige Kæmpe" (243). Han fortsætter: "Medens Barnet voxer, og medens den Mand fødes, oplæres og luttres i haarde Kampe, som Kristus udsaae til at lære Folkene, at ikke Paven men Bibelen var hans Statholder paa Jorden" (244) - altså Martin Luther - vil han for sine læsere udpege det mest bemærkelsesværdige ved det 15. århundrede.

${ }^{44}$ Grundtvig kendte Dante og Tasso fra biografier i Odin Wolffs Journal for Politik, Natur- og Menneske-Kundskab for juni 1804, som han 8.-11. marts 1805 læste i (Albeck 1979, I, 211-216). Deres hovedværker var da ikke oversat til dansk. Dante interesserede navnlig A.W. Schlegel sig for. Steffens havde udtalt sig om Tassos skæbnesvangre elskov i sine utrykte Goethe-forelæsninger i 1803 (Michelsen 1954, 258-261). Petrarca har Grundtvig endnu i 1822 intet fortroligt kendskab til, men kan dog som historiker gisne om ham (Lundgreen-Nielsen 1985, 53). 
I et indskud behandles de næsten samtidige reformerte teologer Jean Calvin (1509-64) og Ulrich Zwingli (1484-1531). Litteraturhistorisk vaktes mangen herlig mand ved "Hans Sachsses Vers" (254) fra Nürnberg, men Zwingli i Genf "manglede hardtad al Poesi", så "en maadelig Oversættelse af Davids Salmer" (255) blev den "uforanderlige Kirkesang" hos hans tilhængere. De var for Grundtvig præget af kold forstandighed og et jordisk frihedssind svarende til hans tidligere udsagn om den romerske kejsertids digtere. Det gjorde dem ukærlige, så de brændte kættere og gik i bogstavelig krig mod katolikkerne. Grundtvigs overbevisning er, at "Det Poetiske hos Mennesket kundgiør sig i Attraa efter, ved det Jordiske at erindres om det Himmelske". Hvor den drift ikke er til stede, står valget kun imellem at give afkald på alt jordisk som munk eller behandle det, som om det har en egenværdi.

Heroverfor satte Luther Bibelen først og sidst og beskuede dens "høie Hemmeligheder som i et Speil" (1 Kor 13,12) og "med Digterøie" (255). Hans bibeloversættelse og kirkesang er hans poesis varige mindesmærker, "dens Kendemærker sees klarlig i hans mageløse Barnesang om Barnet Jesus, den siger med Engelen: fra Himlen høit jeg kommer her, og den er aldeles historisk". Den er skrevet i 1535, men desværre har Grundtvig ikke mere om digteren Luther ud over, at såfremt denne ligesom Hans Sachs havde besunget en anden bedrift end Jesu, ville der nok have været samme forskel på Luthers og Sachs' historiske digte som mellem Luthers lovsange og Sachs' "trohjertige Halleluja" (255). Sachs stod for en meget stor lyrisk og dramatisk produktion, oftest jævn og ligefrem i belærende toner. Ved sin død i 1576 var han den sidste mestersanger, mens Luther havde indledt en ny digterisk periode, som bør opkaldes efter Gud og ham selv, mener Grundtvig.

Englændernes højst ejendommelige sindelag, der "synes at være arvelig paa Halvøen" (260), ${ }^{45}$ modtager ikke godvilligt "nogen Slags Indvirkning fra det faste Land", og det bremser for poetisk vækst. Angelsakserne nævnes slet ikke. ${ }^{46}$ Der kendes dog middelalderballader, mens det om engelsk litteraturs fader, Chaucer (død 1400), hedder, at han "forstod vel at føie sine Ord, men kun til Spot med Daarligt og Helligt og til Sang om ureen Elskov" (261). Chaucers komisk-realistiske forfatterskab bryder med

\footnotetext{
45 "Halvøen" er et lidt sært ord; antagelig mener Grundtvig det halve af øriget England-Skotland (der fra 1707 dannede en union), altså England og Wales.

${ }^{46}$ Grundtvigs undervisningsoptegnelser fra 1809 rummer en omtale af angelsaksiske poeter, der som de eneste nykristne europæere digtede noget betydeligt i modersmålet, og Cædmon fremhæves som digter af kvad, der ligner de islandske (Michelsen 1956, 69). VK 1812 medtager ikke dette, men Cædmon (fra 600-tallet) optræder dog under Spenser og Shakespeare (omkring 1600), fordi Grundtvig trods afstanden på 1000 år! - finder, at de alle tre kom op "mellem Almuen" og "hørte til det forgangne Tidsrum, hvis Bautasten de reiste" (US II, 276).
} 
middelalderens fromme alvor, så Grundtvigs afsky for ham er forståelig nok. $^{47}$

Italiensk renæssancekunst får en hvas karakteristik som en "glimrende" (267 og 268) trældom for folket med Rafael, Correggio og Michelangelo, men reelt var det Italiens "Ligbegængelse" (268). Ifølge Rettelser har Grundtvig glemt, at Michelangelo vist nok foruden maler og skulptør også var digter, og understreger (efter Luk 1,63-64 om Johannes Døberens fader), at "Maleren er den stumme Digter, han maa, som Sakarias, skrive paa Tavlen, fordi han ikke troede Herrens Ord" (398).

Den samtidige poesis heltesange (ved Ariost og Tasso) var "Troens og Fromhedens og Kraftens Ligsange", der netop klang lifligt, men ellers så italienerne "Historiens Aand og Folkenes Velfærd" i idealet "listig Statskonst", et uhyre beskrevet og dyrket af Macchiavelli (268, jf. 265 og 305).

Spansk guldalderdigtning var der mere kraft i. Lope de Vega digtede skuespil i tusindvis, og Cervantes fremstillede "med megen Kløgt" (270) et bagvendt billede af den riddertid, der havde givet Castilien sin tilværelse og glans. "Calderoni" - som Grundtvig to gange kalder dramatikeren Calderón de la Barca ${ }^{48}$ - skrev sine komedier som den sidste navnkundige guldalderspanier. Det udvides dog negativt i Rettelser med, at i hans forfatterskab har Grundtvig som forventet set "en kløgtig Leg med Tanker, Billeder og Velklang" (398), og så lidt han end har læst af ham, mener han, at denne er "hans Kendemærke, thi den driver ingen Digter, uden den er hans Lyst". Han tilføjer: "De nyeste Æstetikeres Lovtaler over ham undre mig ikke, thi de ere hans Frænder". Grundtvig tænker vel på de tyske romantikere Ludwig Tieck og brødrene Friedrich og A.W. Schlegel, især sidstnævnte, der 1803-09 oversatte fem af Calderóns skuespil til tysk.

I Norden er svenskerne først sent samlet i ét rige. De har i oldtiden "ingen Historie" (272) - altså hverken en Saxo eller en Snorre - og er "et vildt eller daadløst Folk" (273). Det ældste svenske digt er Rimkrøniken (fra ca. 1450), der dog er lige så primitivt som den jævne bonde Hjarnes ligvers over Frode Fredegod hos Saxo (Liber 6,1,1 og 6,3,2). I Rettelser forklares yderligere, at svenskerne ikke alene på reformationstiden led af "Umodenhed til ret videnskabelig Syssel" (399), men som folkehelhed savnede "ret aandeligt Alvor" og i kraft af jordisk sindelag som eneste lutherske land fastholdt kirkelig "udvortes Glands og Magt". Derfor har Sverige til dato

\footnotetext{
${ }^{47}$ I VK 1817 kaldes Chaucer en "aandsfattig Hofrimer, der legede med Tungemaal og Vers som med alt baade Guddommeligt og Menneskeligt" (166).

${ }^{48}$ Denne uspanske form er ikke usædvanlig i tiden (jf. Arentzen 1875, 95, note ***). I sin dagbog 24. februar 1805 har Grundtvig dog det rigtige i en omtale af et Oehlenschläger-digt (Albeck 1979, I, 206).
} 
ikke fostret nogen digtere, der kan måle sig med Tysklands og Danmarks. ${ }^{49}$

I England har den bispelige (anglikanske) kirke ikke afsat salmer af værdi, fordi den helt til nutiden er udvortes og jordisk præget; dette er modsat de presbyterianske (engelsk-kalvinske) "mærkværdige [bemaerkelsesvaerdige] kristne Skjalde" (276). Grundtvig mindes dog en "slet Oversættelse af Davids Salmer" (275). ${ }^{50}$ Til dato har England ikke digtet "een gudelig Sang, som kan staa ved Siden af dem, der hos andre Folkeslag udstrømmede rigelig."

Alligevel er det dog i England, at der opstår to skjalde med historiske emner, hvoraf Edmund Spenser (ca. 1552-99) ikke har mange ligemænd og William Shakespeare (1564-1616) ingen overmænd. I The Fairy Queen, 1590-96, søgte Spenser at forevige riddertidens kraft og forherlige mindet om den med dydens glans, "men langt mere ubevidst, og derfor desherligere, bar Shakspeare den forsvundne Tids Billed i sig. Da han var opvoxet uden al lærd Dannelse, forkonstlede han ikke sin Natur og blev en sanddru Tolk af hvad der rørte sig i ham" (276). Hans tragedier er "store Ballader", ${ }^{51}$ og hans historiske "Samtaler" [de nationalhistoriske chronicle plays] er Englands "egenlige Heltedigt" [epos]. ${ }^{52}$ Alle hans stykker opmaner nogle udførte bedrifter og stiller dem til skue, men

${ }^{49}$ Ved sin død 1872 ejede Grundtvig meget få bøger på svensk i sit bibliotek, og trods indbydelser krydsede han i sine mange leveår med bopæl i København og omegn aldrig Øresund for at besøge den fatale nabostat. I Grundtvigs geografi af 1812 regnes norsk kultur selvsagt med til den danske.

${ }^{50}$ Grundtvig kan sigte til Myles Coverdale (1488-1568), som i 1535 oversatte og udgav den første trykte version af hele Bibelen på engelsk. I revideret stand ved ham selv indgik hans Davidssalmer i The Great Bible, 1539-40, som efter kongelig ordre alle engelske kirker skulle eje, og fra 1662 står de også i den anglikanske alterbog The Book of Common Prayer. Coverdale kunne ikke hebraisk og oversatte derfor David fra den latinske Vulgata-bibel suppleret bl.a. med versioner på tysk (Luther). Hans tekst var således andenhånds, hvad Grundtvig måske kunne kalde "slet" ud fra en filologisk betragtning. Moderne forskere fremhæver dog Coverdales evne til at gengive hebraisk poesis karakteristiske brug af parallelismer på engelsk. Grundtvig kunne næppe i 1812 tilstrækkeligt engelsk til at værdsætte den stil, der har holdt Coverdales salmer i brug til i dag. Tak til S.A.J. Bradley for forslaget om denne identifikation. Grundtvig har tidligere kritiseret de reformerte for at fastholde en "maadelig" tysk oversættelse af Davidssalmerne (US II, 255).

${ }^{51}$ Fra sidst i det 18. århundrede bruges ordet 'Ballade' på dansk om et kortere lyrisk-episk og ofte sangbart digt, som formidler en dyster, dramatisk eller eventyrlig stemning.

52 Grundtvig blander i sit billedsprog her gængse litterære genrer sammen, hvad der røber, at han bedømmer Shakespeare fra en læsers synspunkt, ikke fra en teatergængers. 
de undervise og om Forskellen mellem kristelige og hedenske Dramer. Før Kristus saae Digteren og Historieskriveren enhver Begivenhed som en sluttet Kreds; efter Kristus maa de se den som et Led $\mathrm{i}$ en fremløbende Kæde, og, uden at det dog fuldelig lykkes, maa de for at udrive den af sin Sammenhæng, gøre Vold paa deres indvortes Følelse (US II, 276).

Desværre bryder Grundtvig sit ræsonnement af her. Og Shakespeares indsats som komisk dramatiker omtales ikke. ${ }^{53}$

De skotske Ossian-digte, som Grundtvig - efter P.F. Suhms Odin-bog 1771 - regner for historiske sagn, demonstrerer "sanddru", hvor "elendig, midt i sin Kraft, det tænkende Menneske, og hvor forladt Poesien, midt i sin Glands, monne staa, naar Troen paa Guddommen fattes" (277). Som sidste ætling af en herrestamme står den sønneløse ældgamle Ossian, "blind paa Sjælens som Legemets Øie", og kvæder om sine fædres bedrifter, men heltesangen hensmelter i tårer, "thi de Vældige ere henfarne som Veir [vindene] og blevne til sørgende, luftige Skygger [genfcerd]". Her er altså behov for kristendommens komme, og den syntes allerede på Ossians tid ${ }^{54}$ at være lige på grænsen, "rede til at stille den trøstesløse Oldings høie Længsel efter noget Fast og Evigt".

Den engelske bispelige (anglikanske) kirkes digteriske blomster under Karl II var smudsigheder som Samuel Butlers komiske heltedigt Hudibras, 1663-78, der både gjorde nar ad hykleri og ad ægte fromhed og gudsfrygt, mens den populære aristokratiske libertiner John Wilmot Rochester svømmede i uterlighed, og John Dryden, der siden afsvor sin protestantisme, misbrugte sin digtergave til underholdning ved restaurationens kongehof. ${ }^{55}$ "Saare betydningsfuld stod ligeover for dem Presbyterianernes

${ }^{53}$ Under sit første studieophold i England købte Grundtvig ved “et Lykketræf” 20. juni 1829 en indbundet Shakespeare-udgave i 6 bind for $1 £$ hos en boghøkerske i Holborn og læste "dygtig" i den (Grundtvig 1920, 27; Albeck 1979, I, 430). Hans bekendtskab med lystspillene fremgår af to fodnotecitater i NM 1832 fra Much Ado About Nothing (US V, 415-416) og As You Like It (433); navnet Falstaff nævnes (418) med et indirekte citat af den i VK 1812 udeladte Ben Jonson, den førende kritiker i Shakespeares dage.

${ }^{54}$ Suhm daterer "den gamle Caledoniske eller Scottiske Poet Ossian" til det 3. århundrede (e.Kr.) (1771, 18 med fodnote 45). Ossians sange regnes dermed for ældre end de autentiske angelsaksiske kvad fra 600-tallet og frem. Den historiske ægthed af Ossian-digtene blev allerede ved offentliggørelsen 1760-65 anfægtet navnlig i Storbritannien. Nyere forskning antager, at skotten James Macpherson (1736-96) ud fra enkelte gæliske fragmenter og nyere afskrifter af mundtlig irsk og skotsk poesi sammenredigerede og videredigtede på, hvad han betegnede som en engelsk oversættelse af ældgamle heltedigte. På kontinentet begejstredes man for dem et halvt århundrede frem, og debatten om deres status er endnu ikke lukket.

${ }^{55}$ Nogle af de engelske bøger, Grundtvig hænger ud i VK 1812, køber han senere under sine ophold i England 1829-31 og fører dem til København, dels til Det 
Skjald, den fromme, kun udvortes blinde, Milton, og sang med hellig Sørgmodighed om det forlorne [tabte] Paradis" (282) i 1667. I Rettelser tilføjer Grundtvig dog, at Milton snarere sang om presbyterianernes aktuelt tabte paradis $^{56}$ end om Adams og Evas: "Naar den kristelige Poesi begynder saaledes at drømme, da har den ogsaa forloret sit; og det var intet Under, at den forstummede, da den skulde juble over dets Generobring" (400). ${ }^{57}$

Det 15. århundredes Frankrig var ligeledes en sørgelig sag: "Uteerlighed var den almindelige Bedrift, og den var det usle Rimere besang; selv Jesu hellige Levnet udstilledes i Skuespil til Øienslyst" (284), nemlig i en række passionsskuespil opført i stort udstyr. Franskmændene ville ikke give afkald på lystigt liv, "med vanhellige Læber sang Man Davids Salmer som Elskovsviser og Jægersange", og hofdigteren Clément Marot (14961544) udgav i 1542 sin franske oversættelse af 50 af dem, som blev "Hoffets Livsang [yndlingssang]". Ånden skulle være legemets tjener, med gruelige resultater:

En Poesi, der seer dybt i det Endelige og derved opløftes over det, som udtaler henrykt inderlige, hellige Følelser og derved fordunkler de sandselige Glæders tomme Glimmer, kunde ikke trives: smukke Tanker og kolde Billeder, vittigt Fjas, Drilleri og Spil i Vers med mat og eensformig Klang, det var hardtad Alt hvad der kaldte sig Skjaldskab. For saadanne Øine skjule sig Guddommens Spor i det Forbigangne, som i det Nærværende, og Historien maa tykkes at være kun Nysgerrighedens Foderurt, eller Eventyr til Skemt, eller en Fælled, hvor alle Sjæleevner kan drive omkring som lade Øxne [trcege okser], nedtræde, vrage, eller vælge efter eget Tykke (284).

Ludvig XIV (død 1715) havde dannet en europæisk hofkultur med fransk som uundværligt sprog. Det franske akademi (oprettet 1635) skulle under Richelieus ledelse "baade give Love for det Skønne i Vendinger og Ord, og tillige dømme Forfatterne" (286). Normanneren François de Malherbes død i 1628 (som den ældste franske nyklassicist) betød, at "selv de Dygtigste manglede Vinger til høi Flugt". ${ }^{8}$ Alle "middelmaadige Hoveder" underkastede sig akademiets "Aandsslaveri", der var vejen til "Hofgunst og

Kongelige Bibliotek, dels til sig selv. Det gælder fx Butler, Chaucer, Dryden, Grainger og James Thomson (se Personregister i Albeck 1979, II, 237-279).

${ }^{56}$ Ved restaurationen 1660 efter den puritanske diktator Cromwells død blev den presbyterianske lavkirke en taber i England, men dominerede i Skotland.

${ }^{57}$ I det alternative epos Paradise Regained, 1674, slår Milton ind på en argumenterende fortællestil uden poetiske billeder i en lang debat mellem Kristus og Satan. Paradise Lost stod 20. december 1805 i Grundtvigs privatbibliotek på Egeløkke som den eneste repræsentant for engelsk poesi.

${ }^{58}$ Grundtvig sætter Normandiet over alle andre franske landskaber, fordi de norske indvandrere hertil under Rolf (Rollo) forenede legemlig styrke med sans for personlig frihed og uafhængighed og "søgte Helteros" (US II, 223), og disse ædle evner nedarvedes $(222-225,227,229,231)$. 
magelige Dage". Selv de noget begavede blev forkætrede, til de "ogsaa føiede sig, og saaledes udslettede den glattende Fil Kraftens sidste Levninger”. Metaforen røber Grundtvigs sædvanlige afsky for det alt for polerede og harmoniske hos digtere og kunstnere. Pierre Corneille (1606-84), der ligeledes stammede fra Normandiet, søgte i dramatik at genkalde fortidens store ånder, i øvrigt under akademiets modstand, men frembragte kun "halvslebne Normanner" iklædt græsk-romersk dragt. "Idræt [bedrifter] havde de glemt at øve, og det Høieste de kunde, var, at tale et kraftigt Ord til Daads Ihukommelse".

Desværre havde de gotiske [dvs. germanske] sprog efter reformationen kun frembragt bøger af "gudeligt og alvorligt Indhold" (288). Andre muligheder lå ikke åbne, for "til at fordybe sig i Lærdom manglede de Fornemme baade Lyst og Kraft, og at optænke Sminke til Synd eller Hud, det ligger udenfor de nordlige Folkefærds Forstand". Fra Frankrig importeredes i rigt mål "Anstændigheds Kaaber til at skjule alskens Uteerlighed, smudsig, let og vittig Læsning til at ophidse Lysten, neddysse Samvittigheden og fordrive baade Tid og Tanker". Sådanne skatte, ironiserer Grundtvig, "vare overflødelig bag Rhinen at finde", og fransk sprog gjaldt for "Nøgelen til de bedste Kamre". Resultatet blev dog: "Hartad utallige ere de Skrivere, i løs og bunden Stil, hvoraf der vrimlede i det saakaldte Ludvigs Aarhundrede; men de Flestes Navne ere nedsjunkne i den Glemsel, der ene kan formindske deres Eiermænds Brøde". Snildt og dræbende sagt.

Skønt uden Corneilles kraft blomstrede dramatikeren Jean Racine (1639-99) ved "Velklang, Finhed og løselig Tale om Idræt [dåd], Tanker og Følelser". Det var, hvad hans landsmænd og deres efterabere elskede, for "de vare bange for at rystes og se dybt i Mennesket" (288-289); dog tyede han selv som gammel fra "det tomme Gøglespil” (289) til kristendommen.

Moliere (1622-73) beskrives nærmest neutralt for ved "skarpt Øie for det Latterlige og synderlig Gave [scerlig fin evne] til at stille det frem" at have "moret Mange, som søge Glæde i at le, indtil denne Dag" (289). Men den "urene Skemt" hos fabel(gen)digteren Jean de La Fontaine (1621-95) i hans Contes, 1665-74, viser, hvor "saare selv et barnligt Gemyt kan besmittes i en fordærvet Alder". Tidens selvudnævnte filosoffer beviste, at "Egennytte og Sandselighed ere meget naturlige Drifter", og Grundtvig nægter så meget som blot at medtage deres navne.

Et positivt træk er Montesquieus fødsel i 1689, en mand, "som med kristeligt Øie skuede dybt i Folkenes Liv og Vilkaar, og han maa vel agtes som Forløber i den sandere Betragtning af Historien, som i de nordlige Lande skulde vinde Klarhed og Fasthed" (289). Indirekte hylder Grundtvig senere i $V K 1812$ i sit omhyggelige portræt af Tyge Rothe Montesquieus historiske relativisme, nemlig "ei at dømme de forsvundne Tider og de længst hensovne Mænd efter en Maalestok, som da ei var til” (371-372), 
idet dog kun historikerne Johannes von Müller og A.H.C. Heeren med deres navne krediteres for dette. ${ }^{59}$ Man kan rettelig sige, finder Grundtvig, "at der neppe er nogen vigtig Tanke, god eller ond, som ei i Frankrig har havt sit Forbillede, og i alle Dele var Folket 100 Aar forved [foran] Tydskere og Nordboere" (289).

Huguenotten Pierre Bayle (1647-1706) făr et meget slet vidnesbyrd for sin vantro og sin kamp imod kristendommen, som styrkedes ved, at han forblindede folk med tilsyneladende lærd "Kundskab og Indsigt" og ikke var nogen "Blødheds eller Uteerligheds Herold". Den værste bredside i VK 1812 affyrer Grundtvig herefter imod Voltaire (1694-1778), "Kristendommens og alt Helligts arrigste, mageløse Fiende" (290). Han var simpelthen "uden for al Sammenligning". Hvad der af dårlige egenskaber og forkerte synspunkter fandtes spredt på andre af århundredets navne, var "samlet hos ham, og han sluttede Rækken". ${ }^{00} \mathrm{Ud}$ fra hans eget epos om Henrik IV, $L a$ Henriade, ${ }^{61} 1728$, kan alle hans skrifter ironisk betegnes som "Frankrigs Heltedigt" og Lethed", som han havde "i en forbausende Sum". Endog "det Væmmeligste kunde han opsminke, det Klareste kunde han fordreie, og det Ærværdigste syntes latterligt i hans Mund". Det taler til kristendommens fordel, at han "afskyedes som Menneske selv af sine Tilbedere", og at tidsalderen, "der kunde forgude Uhyret", netop manglede kristendom, "men et forfærdende Syn er det at se en Mand, udrustet til at være Slægtens Velgører, ved Hjertets Forvendthed at vorde den til Snare og Fordærvelse." Voltaire gjor-

\footnotetext{
${ }^{59}$ I afhandlingen “Om Mennesket i Verden”, DV II, 1817, kalder Grundtvig derimod den historieskrivning, der vil begrunde kulturelle forskelle på folkeslag og generationer i "Jordbund og Himmelegn og Tilfælde", for "Greb og Slag i Luften, hvorved Intet løses" (174). I VK 1817 hedder det endnu mere resolut om Montesquieus "forroeste" hovedværk (De l'Esprit de lois, 1748), at det i sin ligegyldighed over for religion er "luftigt og let, vandet og klart" (304). Grundtvig konkluderer: "Skjævt og bagvendt er det Hele, men Vinden [forten; en svag fornemmelse] af historisk Vidskab hjemler det sin Forfatter, og videre kom Franskmænd aldrig" (305).

${ }^{60}$ Portrættet gentages neddæmpet i Grundtvig 1815b, 54-60, og forkortet i VK 1817, 300-302. I et udkast til en ikke-realiseret fortsættelse i 1845-46 af Haandbog i Verdens-Historien vender Grundtvig tilbage til Voltaire som et tidssymbol (Vind 1999, 394-395). Grundtvig læste i september-oktober 1799 i Århus J.G. Schummels roman imod fritænkeri Der kleine Voltäre, 542 sider på dansk ved Niels Prahl 1794 (efter 2. udg. 1785), tilegnet N.E. Balle. Her tager måske hans senere Voltaire-fobi sin begyndelse (Albeck 1979, I, 9; Lundgreen-Nielsen 1980, 43-44).

${ }^{61}$ Ifølge en senere offentlig indrømmelse er Henriaden Grundtvig "ubekiendt" (Grundtvig 1815b, 57). Auktionskataloget fra 1873 over Grundtvigs bøger talte dog 10 bind af Voltaire på fransk samt 1 på engelsk.

${ }^{62}$ Ordet "Heltedigt" er her en udsøgt hån, hvor det ved Shakespeare var den højeste ros (US II, 290 og 276).
} 
de sig ydermere til "Encyklopædisternes (Kredsløbernes) Formand", og gudsfornægtere som d'Alembert og Diderot skrev kløgtigt i encyklopædien 1751-72, "dette ugudelige og grundløse Skrift", der i Frankrig fik ry for at samle al menneskelig visdom. Frederik den Store af Preussen, der afsvor tro på den sande Gud og evigheden og gjorde jordisk "Ære og Magt" (304) til sine afguder, er Voltaire med til at more og fremme vantro hos (gennem livslang brevveksling og under opholdet ved hoffet i Berlin og Potsdam 1750-53). Videre i VK 1812 fremhæver Grundtvig Voltaires afgørende indflydelse for synet på de modreformatoriske jesuitter, som han lærte folk "baade at foragte og undvære" (336).

Tilbage til Voltaire som historisk ciffer. Katarina II af Rusland var "oplyst i Voltæres Smag", hvilket gør et folk uroligt og dets regerende "herskesyge og ærelystne" (338). I Danmark repræsenteredes Voltaires ånd af den holstenske læge J.F. Struensee med hans ubegrænsede trykkefrihed, der måtte udbrede "Vantro og Ryggesløshed" (368) og opmuntre "Liderlighed"; pressen blev frigivet, så "alskens Uhumskhed navnløs udstrømmede af sit skidne Kildespring". Grundtvigs konstatering af Voltaires hyldestrimbrev til Christian VII i anledning af forordningen af 14. september 1770 er sjældent hadefuld i formuleringen: "Det gamle Skarn i Ferney jublede paa Gravsens Bred". ${ }^{63}$ Struensee fastholdt dog kun kortvarigt sin magt, og i hans henrettelse i 1772 finder Grundtvig frelsen for Danmarks kristendom. Den kristelige historiker Tyge Rothe (1731-95) udskammede "med høien Røst" (372) Europa for planer om at rejse et æreminde for Voltaire. ${ }^{64}$ Franskmændene var, fortsætter Grundtvig, desværre inspireret

${ }^{63}$ Voltaire var fyldt 75 år ved forordningens udstedelse i 1770, men døde dog først 30. maj 1778. Grundtvig ejede Voltaires hyldest til Christian VII (trykt i København på fransk) i sin bogsamling (auktionskataloget 1873, nr. 7010).

${ }^{64}$ I 1770 tog Suzanne Necker, den franske finansministers hustru, initiativet til at få skabt en statue af Voltaire, støttet af en kreds, der navnlig talte medvirkende ved den store franske Encyklopædi. Christian VII sendte et bidrag til indsamlingen. Billedhuggeren Jean-Baptiste Pigalle (1714-85) rejste til Ferney for at træffe Voltaire og studere hans ansigtstræk og afleverede i 1776 en marmorstatue i naturlig størrelse (nu på Louvre). Den blev en skandalesucces, fordi Voltaire sås som en gammel mand, siddende splitternøgen med en togalignende kappe lagt over ryggen og delvis ned om de spredte oldingemagre ben. I 1779 udsendte Rothe en 86 siders pjece under navn af Undersøgelse om ikke Aresminder, hvilke offentligen og uden Betingelse oprettedes for Voltcere, vare til Haan for vor Levetid og dens Philosopher, hvori tesen i titlen bekræftedes. Rothes samtidige læredigt Udsigter over Menneskets Bestemmelse (på i alt 354 s.) indeholder i øvrigt et kritisk 20 verslinjers portræt af Voltaire med den besudlede lire som en mand, der kun er positiv på grund af de anderledes ædle kræfter, han kalder frem til modstand og modsigelse (Rothe 1779-81, 333-334). I sin ungdom priste Rothe derimod Voltaires La Henriade som et æremæle for Frankrigs bedste konge, bygget på sandheds grund (Rothe 1759, 186-187). 
af engelske tænkere som Francis Bacon, Thomas Hobbes og John Locke til at slå ind på en opfattelse af religion som kun en ydre indretning i staten, men en "ligegyldig Ting for det indvortes Menneske" (290-291). Deraf udledtes en forkert livsopfattelse, som tog "Erfaringen for al Sandheds Kilde og den almindelige Menneskeforstand for Overdommer" (291).

Det i 1812 stadig politisk splittede Tyskland kendes på åndsytringer, "hvor Alt synes som Bølger at have løftet og sænket sig, skummet og bruset efter sære Luner". Disse kan, vurderer Grundtvig, ikke forklares nu, men måske om hundrede år. "Det eneste almindelige Kendemærke hos Tydskerne er da en uslukkelig Tørst efter Indsigt i Tingenes inderste Væsen". ${ }^{65}$ Fra den stammer da "den synderlige [scerlige] Ustadighed og de forvovne Spring fra den ene til den anden Yderlighed, men deraf ogsaa den Alvor, hvormed de haandtere det Mindste som det Største, det Afsindigste som det Klogeste, efter som de hist eller her vente at finde al Visdoms Kilde" (291-292). Grundtvig fortsætter: "Dette Grundtræk avlede Reformationen, det har avlet stor Galskab, megen Tvist og unyttig Handel, men det har bevaret Folket og Europa fra ganske at foragte den Røst i vort Indvortes, som vidner at Alt under Solen er Forfængelighed og kun en Skygge af det Tilkommende" (jf. Præd 9,3, Kol 2,17 og Hebr 10,1) (292). Her kaldes så naturligvis Luther og hans ordensbrødre frem, men der kommer intet om salmedigtning ud over, at "den sidste herlige Genlyd af Luthersk Poesi" (293) hørtes hos meissneren Paul Gerhardt (1607-76). Samtidig digtede schlesieren Martin Opitz (15971639) verdsligt, men de, som fra Luther havde fået "nogen Ahnelse om Poesi", så straks, at han ikke var "begeistret". ${ }^{66}$ Over tysk barokdigtning ${ }^{67}$ fældes en hård dom: Hoffmanswaldau og Lohenstein med efterabere ville lade, som om de begejstredes, men frembragte kun "Svulst og Ordbram".

Siden fulgte så pietismen med sine vildveje. Grev Zinzendorf (170060) fremkalder en strøm af skældsord fra Grundtvig (301-302: 'ugudelig; kødelig; Urenhed; hyklerisk; bespotte; bedrage; ukristelig; spotte; væmmelig; ubibelsk; elendig; usømmelig; falsk; Løgn; vanære; vanhellige'). Det ville være endt med tysk kristendoms dødsfald uden hædrende

${ }^{65}$ Formuleringen er vel et citat af forste scene af Goethes Faust (såvel Ein Fragment, 1790, som Erster Teil, 1808), hvor titelpersonens ønske lyder, "Dass ich erkenne, was die Welt / Im Innersten zusammenhält"“.

66 'Begejstring' er et forholdsvis nyt låneord på dansk (jf. Videnskabernes Selskabs Dansk Ordbog, I, tr. 1784, udg. 1793). Skønt Johs. Ewald (død 1781) i høj grad kender tilstanden og de stemninger, den fremkalder, bruger han aldrig ordet. Derimod har Baggesen det et tiår senere, og det er Oehlenschläger, der knæsætter det på dansk 1802 ff. (Andersen 1900, 144-156). Når Grundtvig skriver "begeistret" i 1812, betyder det en af det guddommelige henreven tilstand.

${ }^{67}$ Betegnelsen og ordet "barok" kendes som litterær periode- eller stilbetegnelse $i k k e$ af Grundtvig eller hans samtid. 
bisættelse, hvis ikke krisen også var gået nogle digtere til hjertet, ganske vist i egenskab af "Ligskjalde" (302), nemlig Johann Cramer, Adolph Schlegel og især F.G. Klopstock (1724-1803). Sidstnævntes hovedværk, Messiaden, 1748-72, rejser Kristus et monument som "Menneskeslægtens guddommelige Helt", men regner ham nærmest for en halvglemt bedrift. I Grundtvigs øren mangler denne digtning sammensmeltende toner " $\mathrm{i}$ liflig Klang", kun "dunkle og afbrudte stride de sig frem", og Frelseren er opfaret fra tidens hjerte. Digterens fantasi søger forgæves at hente ham ned fra de høje himle, men "forvildes mellem Skyerne, mattes og synker til Jord." Det samme gælder Klopstocks verdslige læsedramatik om keruskeren Herman (Arminius), "et fabelagtigt Mindekvad, en glimrende Udsmykkelse af Oldtidens løse Sagn” (302-303). Grundtvigs tre adjektiver er alle negative ved at fremhæve det utroværdige, det kun på og fra overfladen skinnende og det upålidelige. Men i Norden, "hvor kristen Tro end ei var saa sjelden" (303), altså præcisere dateret i Klopstocks københavnerår 1751-70, stemte hans toner "endog en anden Harpe, værdig til at lyde i Samklang" - en utvivlsom hentydning til Johannes Ewald. Klopstock fik sine landsmænd til at skamme sig over deres forkærlighed for "den tomme Bjeldeklang, de ugudelige Nidviser og det liderlige Fløitespil" fra Frankrig. Her afslører billedsproget for resten lidt tilfældigt Grundtvigs misforhold til musikalske udtryk. Videre finder han, at selv om digtere som Gellert, Rabener og Hagedorn var bedre moralister end poeter, kom den største trussel dog fra Preussen med kong Frederik den Store. Han levede kun i tiden og ville bruge den, når han behandlede mennesker som livløse ting og bedømte alt efter dets bekvemhed til at tjene til redskab for sine foretagender. Han dyrkede Voltaire og andre ugudelige franskmænd, dels for at more sig, dels af egen digterforfængelighed. Han foretrak konversation på fransk og skrev endog franske vers, som han ville roses for. Derimod foragtede han "tydsk Skrift" (305) - fordi, mener Grundtvig, "den var ham for dyb, alvorlig og kristelig". 68

Englands 1600-tal blev en urolig tid med skift af kongehus og med borgerkrig fulgt af en midlertidig republik, kvækere og endelig et retableret kongestyre. Den bispelige kirke fik sin fornuftsdigter med "den tænksomme men dybt fordærvede Pope, ja selv i Addison en Dydens og Fornuftens Talsmand, der bedre end hans fleste Landsmænd forstod at vurdere Kristendommen og dens elskværdige Datter: det ydmyge, barnlige Sind" (308). Popes fordærvelse udlægges ikke her. ${ }^{69}$

\footnotetext{
${ }^{68}$ Grundtvig tillægger faktisk Frederik et had til tysk, fordi han var ateist. Årsagen var snarere, at tysk som konversationssprog var uudviklet i forhold til fransk, og at kongens mundtlige tysk ifølge ham selv var på niveau med en hyrekusks.

${ }^{69}$ Af Grundtvigs beskrivelse af Pope fem år senere fremgår, at han var katolik, gjaldt som en mageløs mester i rim, oversatte Homer og selv digtede om menne-
} 
I Danmarks 17. århundrede "sang Anders Arbo [dvs. Arrebo] ret liflig om Skaberværkets Gang" (315), oversatte Davids salmer "med Fynd", men digtede ingen selv; C.C. Lyschander "besang ei verdslige Handler ilde", hvad derimod kollegaen Henrik Gerner gjorde - og "til gudelig Sang vare de ei oplagte". Det gjaldt også Anders Bording. Men Thomas Kingo (1634-1703), sønnesøn af en skotsk indvandrer (som Gud førte til Danmark), "digtede Psalmer, som vel mangensteds ere fortrængte, men ei eftergjorte, endsige overgaaede" (jf. Grundtvigs karakteristik af Shakespeare, der ingen "Overmand" havde, 276).

Grundtvig nærer fortsat skepsis til engelsk litteratur i det 18. århundrede på grund af forsømt kristendom (trods kvækere og metodister). Hans opremsning er medrivende. Edward Young skrev The Complaint: or, Night-Thoughts on Life, Death, \& Immortality, 1742-45, "svare Nattetanker og tungsindige Gravsange" (320), i satiren The Centaur not Fabulous, 1755, malede han ved dyremenneskets sidste timer sit fædrelands fremtidsskæbne "med gloende Farver" og kaldes dog "den kristelige Digter". Jonathan Swift opslog en "vild Latter over Fordærvelsen" og endte sit liv i dårekisten. Samuel Richardson og Oliver Goldsmith, begge forfattere af samtidsromaner, skildrede udførligt "den forsvundne Dyd", mens de mindre realistiske kolleger Laurence Sterne, Henry Fielding og Tobias Smollett udgav "løierlige, tildels smudsige Eventyr". Den skotske landskabslyriker James Thomson udfærdigede i The Seasons, 1726-30, "tomme Malerier af Naturen" parallelt med, at Edward Gibbon (1737-94) som tidens eneste duelige historiker udlagde Romerrigets "Synken og Undergang" (The History of the Decline and Fall of the Roman Empire, 1776-88). I teatret gik man for at "le ad Footes Gøglespil, more sig ved Skyggen [en ringe gengivelse] af sine egne Rænker og Daarligheder og bevæges ved Billedet af den Elendighed og de Lidelser, som Man i Verden gik kold forbi og tit selv foraarsagede".${ }^{70}$ Det borgerligt realistiske samtidsdrama fik ingen beundrer i teaterhaderen Grundtvig. Derimod evnede han ganske kort at hamre navne og titler på plads i sin historiske fremstilling. Jo vredere des mere rammende.

sket (i Essay on Man, 1743-44). Grundtvig fraskriver dog her Pope det "mindste Begreb om Poesie" (VK 1817, 341) og kalder hans Homer på engelsk "kun et meget maadeligt Riim-Fabrik af fembenede Jamber". Pope har brugt sine gaver som "Spot-Rimer" (342) i sin Dunciade, anonymt udgivet i 1728 (men vedkendt 1735), en satire over middelmådigheds og dårlig smags sejr ved dumrianer (på engelsk 'dunces'). Grundtvig mener alternativt, at Pope dog uheldigt nok i sin kampagne har glemt just "een slet Digter som fortjende de fleste Snert", nemlig sig selv.

${ }^{70}$ Den ikke særligt geniale London-skuespiller og lystspilforfatter Samuel Foote (1720-77) søgte og vandt popularitet ved på scenen at kopiere dalevende personer. 
"Uden Tro paa et Forsyn, uden mindste Forstand paa høiere Aandelighed og uden Kundskab til Englands Oldtid" skrev David Hume en englandshistorie (i 6 bind 1754-62), der snart blev "ophøiet som et Mønster":

Det kom deraf, at man her syntes at se Spiret faldet af Guds Haand og i den klare Fremstilling af lutter Tilfælde og Ondskaber, Daarligheder, Kneb og Rænker havde man et Skuespil i det Store, som ret kan gotte høie [indbildske] Øine og vantro Hjerter. Denne Mand kaldte sig ogsaa Philosoph, fordi han kunde bevise, at han selv ei havde Lyst til at modtage andre Indtryk eller Tanker, end dem der paatvinge sig gennem de udvortes Sandser (320321).

I Tyskland under den vantro monark Frederik den Store "udsang" (321) Klopstock og hans åndelige brødre så den gamle troende tidsalder. ${ }^{71}$ Samtidig får schwaberen C.F. Wieland (1733-1813) rollen som tysk Voltaire. Han gjorde dog ikke i religionsspot, men forlystede folk "med Leveklogskab, Vittighed, letfærdigt Skemt og alskens Gøgleri i velklingende Vers og flydende Stil’. Som den første tysker legede han ret "med Aandeverdnen og indgød derved Dristighed til at le ad alt Oversandseligt" og opelskede også på tysk romangenren, “dette Ukrud, der som en Snyltevext omsnoer alle aandelige Planter og røver dem de sidste Safter, uden selv at vinde nogen Størke". Men romaner og skuespil kan kun elskes $\mathrm{i}$ en tid, der har mistet kraften til "dyb Følelse og stor Idræt [dåd]", og begge bidrager "mægtig" til at nedbryde "Frbødigheden for det Sande, baade i Følelse og Historie".

De tyske universiteter arbejdede på at kassere kristendommen under påskud af at ville gøre den "fornuftig" (322). I Berlin fremmede samtidig den rationalistiske Lessing-tilhænger, forlæggeren og boghandleren C.F. Nicolai (1733-1811) sammen med en højrøstet flok oplysningsmænd den visdom, at forstanden, legemet og materiel nytte i det daglige liv var livets mening. Parallelt hermed gik det preussiske skolevæsen over til en indlæring bygget udelukkende på realviden. Det opfatter Grundtvig ironisk som en ægte "Boghandleroplysning" (323) og forkorter det til et program om, "hvordan man skal stile sin Sag for at komme ustraffet, uskammet og bekvemt igennem Verden". Grundtvig tænker navnlig på "den ugudelige Basedov, der i sit hele Liv lod se sin Forkærlighed for den uterlige Ryggesløshed, hvori han var opgroet paa Hamborgs Gader". 72

\footnotetext{
${ }^{71}$ Verbet "synge ud" brugtes på dansk, når en død under salmesang blev båret ud af sit hjem for at blive bisat.

${ }^{72}$ I Rettelser meddeler Grundtvig, at han her sigter til grev Frederik Daneskjolds memorial imod J.B. Basedow (1724-90) (US II, 390), som han antagelig kender fra et tryk i Nyerups Luxdorphiana, I, 1791, 22-48 (Bugge 1965, 175, note 37). Daneskjold (1703-70), der ellers var ansat i Søetaten (flåden), kæmpede som overhofmester 1760-64 på Sorø Akademi imod Basedows ugudelighed i det professo-
} 
Ædlere, "skøndt ogsaa vildfarende", var Rousseau i Genf (323), der dog desværre var "Ukristen" (324) og ikke fandt hjertets fred. Hans forkerte naturfilosofi og opdragelsessigte drøftes i et længere afsnit, men uden "Guds Ord" fór han "vild i Tankens Irgang". Grundtvig medtager ikke nogen titler fra Rousseaus mislykkede forfatterskab, selvom denne skrev en "heel" bog for at belyse en ny opdragelses- og undervisningsmåde "i sin hele bagvendte og latterlige Skikkelse" (en hentydning til romanen Émile ou l'éducation, 1762, på dansk 1796-99).

Dog nævnes det videre - vist nok som positivt - at Wieland oversatte Shakespeare (22 dramaer i prosa 1762-66) i stedet for som Voltaire at håne og plyndre ham (325). Det delte de "skrivende Aber" (små kopierende ånder) i to partier, ét, der ville ligne Shakespeare selv, og ét, der ville ligne hans tyske oversætter (326) og "udsmykkede Skabilkener, i snesetal, med de stjaalne Klædebon". Derved blev tyskerne fordelagtigt mindet om, at ikke alle anså Voltaire for at være "Digterhøvdingen".

Den ligeledes ikke-kristne G.E. Lessing (1729-81) gen(op)fandt Aristoteles' antikke poetik. Grundtvig undrer sig over, at "denne hedenske Grubler, som i de fleste Dele ei giorde Andet end at betragte Forgængernes Værker og Tankerækker med kold Opmærksomhed”, værdsættes så højt af kristne. ${ }^{73}$ Grundtvigs forklaring på det lyder, at ingen, der afviser kristendommen, kan vinde den art urokkelig fred og ro "med sig selv", der kræves for at skelne og ordne, medmindre han taber Gud aldeles af sigte. Lessing angreb brøstfældigheden i sin tids kristne lærebygning og gjorde i sit skuespil Nathan der Weise, 1779, kristendommen til en relativ religion iblandt andre, der kan gælde, indtil forstanden vokser op og bliver myndig. Han satte derfor "Naturens Efterligning som Digtekonstens Opgave". Denne lov vil dog ophæve al poesi, som "netop bestaar i Beskuelsen af det Jordiskes underordnede Forbindelse med det Himmelske" (327), men den blev alligevel herskende i tidsalderen.

Dog lød også åndigere røster i Tyskland. Først og bedst er frankfurteren Goethe (1749-1832), "det mest opvakte Hoved, Tydskland i mere end

rat (i moralfilosofi og tysk), denne beklædte dèr siden 1753. 1761 lykkedes det at forflytte Basedow til gymnasiet i Altona, hvorfra han blev afskediget i 1768. Grundtvig ser også i VK 1817 Basedow som "et udsvævende og halvgalt Menneske" fra Hamburg (US III, 675). Grundtvig mener, at just Hamburgs gader fremmer uterlighed. Hans rejser til England 1830, 1831 og 1843 gik med skib fra Hamburg, men før den tid havde han dog ikke besøgt byen. Baggrunden er måske Jens Baggesens meget negative indledningsvignet af kræmmerbyen i det første kapitel betitlet "Hamburg" i Labyrinten, I, 1792, med nogle omtaler af de korte, smalle, smudsige og afskyelige smågader og mørke "Peermadsensgange". Peder Madsens Gang var navnet på et berygtet bordel- og forbryderkvarter i København (der nu i kraftigt renoveret stand udgør Ny Østergade).

${ }^{73}$ Det kan bemærkes, at i gennemskuelsen af Aristoteles' kulde er Grundtvig også iskold. 
to Aarhundreder fostrede" (327) - med andre ord: siden Luther. Dramaet Götz von Berlichingen mit der eisernen Hand, 1773, var et prægtigt mindesmærke for riddertiden og overtrådte i formen (med despekt for nyklassicismens tre enheder og skrevet på prosa) "alle de Regler, Man havde udtænkt for Dramaet, i det Man gik ud fra den bagvendte Mening, at Digteren skulde have til Øiemed, ei at fremstille et tro, livligt Billede af Tid og Idrætter [bedrifter], men at sammensætte et Gøglespil, som kunde være til Øienslyst og Roskab [morskab] for aandelige Lediggængere". Goethes store kald var "at oplive Krøniken og forfærde Dværgeætten med sine Kæmpefædre" - altså fremholde noget sandt historisk for at få nutiden til at se sit lille format i forhold til tidligere slægter. Men desværre opgav Goethe dette. ${ }^{74}$ Romanen Die Leiden des jungen Werthers, 1774, åbenbarede, at titelpersonens inderste dybe længsler bevirkede et frafald fra troen og et både fortvivlet og forgæves forsøg på at vinde jordisk tilfredsstillelse, og det måtte ende ufrugtbart med døden. ${ }^{75}$ Goethes Faust-figur (i Faust, ein Fragment, 1790, ${ }^{76}$ og Faust, der Tragödie erster Teil, $1808^{77}$ ) slukkede sin tørst efter indsigt og lyksalighed i en pagt med Djævelen, men her blev Goethe bange for sine egne tanker og vendte sig bort. ${ }^{78}$ Senere $i$ VK 1812 under tysk højromantik anfører Grundtvig, at Schellings tilhængere "med Velbehag" spejler sig i Goethes Faust (352), og at Goethe "paa en Maade var Naturfilosofiens rette Fader" (353). Det er ingen ros.

Goethe ville i resten af forfatterskabet gøre et kompromis og "laane det Jordiske en høiere Glands" (327), så det blev tilfredsstillende, og "hans senere Værker ere, fra Konstens Side, Mesterstykker, men dyrekøbt er deres Runding, og de synes mere skikkede til at inddysse Tidsalderen end vække den; derfor er han ogsaa for dem blevet prist ligesaa overmaade, som han blev lastet og spottet for de første." Dette er nok en tese fra Steffens' Goethe-forelæsninger i 1803. Iphigenia auf Tauris, 1787, efterligner

\footnotetext{
${ }^{74}$ Grundtvigs ræsonnement skiller dermed Goethe fra Æschylos, Shakespeare og Corneille (US II, 199, 276 og 286).

${ }^{75}$ Werthers selvmord var kristent og kirkeligt set en forkastelig handling. Romanens sidste to sætninger beskriver hans natlige begravelse: "Handwerker trugen ihn. Kein Geistlicher hat ihn begleitet."

${ }^{76}$ Det trykte Fragment skal have været Steffens' yndlingstekst, som han kunne udenad, men den færdige part 1 fyldte ham med grænseløs smerte over afrundingen af handlingen (jf. hans selvbiografi Was ich erlebte, I-X, 1840-44, LundgreenNielsen 1971, 129, note 43). I sine københavnerforelæsninger over Goethe i 1803 kender Steffens således udelukkende til Faust-fragmentet.

${ }^{77}$ Ifølge en boghandlerregning købte Grundtvig Goethes Faust [I] 12. januar 1810 (Fasc. 521.1).

${ }^{78}$ Faust, der Tragödie zweiter Teil offentliggjordes efter Goethes bestemmelse først posthumt $i$ hans dødsår 1832. Om Grundtvig har kendt eller læst den, vides vistnok ikke.
} 
"til Skemt", altså underholdning, det antikke græske drama, mens tragedierne Tasso, 1790, og Egmont, 1788, ved deres hovedpersoner den italienske hofdigter og den nederlandske grevelige frihedshelt viser, "at Man kommer galt afsted, naar Man ei vil være klog efter Verdens Viis". Romanen Wilhelm Meisters Lehrjahre, 1795-96, demonstrerer, "hvor herlig Man kan leve, naar Man forstaar at bruge Verden med Smag”. Både disse sjusket uddragne moraler og deres sprogtone signalerer Grundtvigs manglende interesse for Goethes forfatterskab. Han miskender egentlig ikke hans format eller evner, men angriber hans faktiske karriere. Hvor Goethe kunne være blevet sin tids påkrævede vækker, foretrak han sympatiserende at skildre det jordiske liv. ${ }^{79}$

Württembergeren Friedrich Schiller (1759-1805) behandles egentlig mere kritisk af Grundtvig. Hans skuespil Die Räuber, 1782, vendte sig imod alt nederdrægtigt i tiden, hvad der muliggjorde et kristent historiesyn, men det tabte sig i grublen, for Schiller kendte til hjertets trang, ikke dets trøst. Han omdigtede i historisk dramatik både personer og begivenheder efter de nærmeste årsager, han kunne forestille sig (Don Carlos, 1787; Wallenstein, 1796-99) for "at fremkonstle et afrundet Heelt" (328), altså en gentagelse af Goethes hovedfejl ( $\mathrm{og}$ af Molbechs pragmatisme som historiker). Sandest og mest poetisk var han i Jeanne d'Arc-dramaet Die Jungfrau von Orleans, 1801, der handlede om troens hemmelighed. Grundtvigs slutdom bliver dog blidere end ved Goethe, måske fordi Schiller døde knap 46 år gammel. Han nåede ikke frem til kristendommen, vandrede så smertefuld "ved egen Brøde" og blev ikke, hvad han havde evner til. Men trods alt stred han mod det usle og syndige, knælede for Gud og bevarede "en i hans Tid sielden, vel desværre indskrænket men uskrømtet Ærbødighed for Kristendommen og de hellige Skrifter". Schillers ærlighed synes at redde ham fra at blive forkastet. Men præmisserne ligner dem, hvormed Grundtvig fælder Goethe.

\footnotetext{
${ }^{79}$ I sin store prisbelønnede afhandling "Goethe og Danmark" (i Goethe-Jahrbuch for 1881) sætter Georg Brandes Grundtvigs Goethe-portræt i VK 1812 op over for negative ytringer fra andre danske samtidige (Chr. Bredahl, Nicolai Søtoft, Ingemann, Jens Paludan-Müller, J.P. Mynster): "Mere fængslende (...) er N.F.S. Grundtvigs langt mer barokke, men langt friskere Udtalelser" (Brandes 1899, 284). Ordet "barok", der på denne tid endnu ikke er blevet til en litterær eller kunsthistorisk periodebetegnelse, betyder noget sælsomt, overraskende eller groft urimeligt. I et brev fra London 4. august 1830 til Lise Blicher erklærer Grundtvig, at "en barokkere Smag end den Engelske vil neppe findes", fordi nogle damer vil fraliste ham en autograf, der skal "giemmes som en Reliquie" (Grundtvig 1920, 118). Grundtvigs afvisninger af Goethe skærpes i øvrigt i $V K$ 1817, hvor han udnævnes til "den tydske, eller vel tydeligere, den virkelige Voltaire", som havde "Magt", hvor franskmanden nøjedes med et "Skin" deraf (US III, 715-717). Her affærdiges romanen Die Wahlverwandtschaften, 1809, som blot naturhistorie over menneskelige lidenskabers "chemiske Sammentræk og Sammentræf".
} 
Samtidig med disse dramatikere - hvis uovertrufne lyrik Grundtvig springer helt over - kom der bemærkelsesværdig sang fra mecklenburgeren Johann Heinrich Voss (1751-1826) i hans idylliske heksameterepos om en tysk præstegård, Luise, 1795, som "med Ret" er blevet berømt. Det foranlediger Grundtvig til et tilbageblik på idylgenren:

Idyl var hos Græker og Latiner en Fremstilling af det rolige, mere kærlige og skyldfri Hyrdeliv, deres Fædre virkelig havde ført. I den ny Tid skinne de gamles Værker baade som Ledestjerner og Løgtemænd, og Mange vare de som indbildte sig, at Man efter de gamle Mønstre kunde skrive Hyrdedigte, hvad Folk Man end var af; isteden for at betænke, hvorfor Schveitseren Gesner ene forstod at haandtere Hyrdefløiten, størkede man sig ved hans Sang i Vildfarelsen (328).

Lidt senere i VK 1812 beskrives Salomon Gessners idyller (1756 ff.) og J.C. Lavaters folkesange (Schweizerlieder, 1757) som Schweiz' "Ligpsalmer" i nutiden (347).

Klogere end flertallet af hyrdedigtere var dog Voss, der let fandt den rette tone ved at indse, at "Hos hvert troende Folk føres langt fra glimrende Bedrift og store Stæders Tummel et Landliv, hvis Minde, naar det ganske eller næsten er forbi, maa begeistre et stille Gemyt til vemodig Sang" (328). ${ }^{80}$ Kun var Voss desværre selv for lidt kristen til at forstå, hvad der "udbredte den milde Rolighed", nemlig troen på Kristus. Og når han anslog andre tunger (saksisk eller nedertysk dialekt), blev det, "som naar en ærlig Bondemand vil tale pænt og høitravende, mer end omsonst" (329).

Voss' højtyske Homer-oversættelser - Odysseen, 1777, og Iliaden, 1793 - roser Grundtvig især for den idylliske tone i den førstnævnte. Friedrich Leopold Stolbergs Homer-oversættelse (Iliaden, 1778, for første gang på tysk) er dog bedre. Han oversatte også Ossian, I-III, $1806 .{ }^{81}$ Men udbredelsen af klassikertekster er trods sin nytte et ondt forvarsel. ${ }^{82}$ Det forklarer Grundtvig lidt senere, da han i Christian VI's regeringstid passerer historikeren og udgiveren Jacob Langebek (1710-75) og hans Danske Selskab for Fædrelandets Historie 1745 ff.,

\footnotetext{
${ }^{80}$ Vel med andre ord i $V K$ 1812's sammenhæng også, fordi disse fredelige landboer var sene efterkommere af Abel og af hans broder Sets naturnære æt.

${ }^{81}$ Dette værk modtog Grundtvig efter eget valg som afskedsgave fra medlemmerne, da han forlod formandsposten i Det Langelandske Læseselskab 14. januar 1808 .

${ }^{82}$ Parallelt hermed erklærer Grundtvig i Rettelser, at det Academie joyeuse i Toulouse 1323 ff., som skulle redde den "døende Aandelighed" i den provençalske digtekunst, resulterede i, at der fra "den Stund lød ei en Sang, der var værd at høre" (US II, 410). Årsagen er, at guld og ære ikke kan opvække hoveder, men må fordærve de opvakte, som stræber derefter.
} 
det er, som om Folket paa Gravsens Bred skrev sit Testamente, og overlod Godset, det ei længer selv kunde bruge, til en kommende Slægt. Det er Tegn til, at Enkeltes Hierter end hænge ved Fortiden med dens Bedrift, men kan ikke i Hovedet samle dens Billede, og samle da dens Levninger i en Dynge, for at de dog ikke skal adsplittes i den tilstundende Nat (364).

Pessimismen slår igennem i de sidste tre ord (vist fra Joh 9,4).

Et dårligt tegn er det også, når man indsamler folkepoesi. Det begyndte preusseren J.G. Herder (1744-1803) med, skønt han på mange måder var en "herlig" mand (329). Trods sin kristendom stod han ligesom folkesangene "paa Grændsen af Religion, Poesi og Historie" og gjorde bemærkelsesværdige udvandringer til alle sider uden at nå "et Stade, hvorfra han kunde ei blot overse [fä overblik over], men paa menneskelig Vis gennemskue hvad han syslede med". Ydermere ville han fejlagtigt gøre kristendommen tækkelig for vantro ved at redegøre for skønheden i den hebraiske poesi. Positivt udvirkede han dog derved, at de hellige skrifter ikke blev glemt, "og under den vanhellige Stræben efter at udslette det Guddommeliges Spor har Man sammenslæbt en Dynge af Lærdom, som under Troens Hænder engang vil tjene til end mere at forherlige den Aand, der saa hørlig taler igennem dem". Herder oversatte selv adskillige hellige digte, men fik desværre ukristne efterfølgere, som ikke respekterede disses åndelige art og derfor nødvendigt måtte "udvande og forvanske dem".

I "Krønikens Betragtning" (historiesynet) stod Schiller og Herder "hardtad jevnsides", men Herder så dog dybest. Under megen modsigelse "udgik fra dem en Synsmaade for de svundne Tider, som maa tilintetgøre det usle Spil med Tilfælde og smaa Aarsager til de største Begivenheder, i det Guddommens Finger aabenbares" (329-330). De gjorde således op med den pragmatiske historieskrivning. "Dog var dette hos begge mere Ahnelse, end Tro og klart Syn, de laa i Strid med sig selv" (330), og i Schillers bøger om Nederlandenes Frafald, 1788, og Trediveaarskrigen, 1791-93, syntes også meningen eller anelsen glemt. Grundtvig tilføjer følgende hjertesuk som nulevende historiker:

Hin Synsmaade var slet ikke i Tidsalderens Smag, der kun vilde speile sig selv i Alt, og i al Fald heller omtumles af blinde Tilfælde, end styres af et viist og kærligt Forsyn. Synderen skælver for Herrens Røst og bag Træerne vil han skjule sig som Adam. Hvo der med Bifald vilde sysle med Krøniken maatte enten udstaffere [oppynte] den til Roman, eller med vigtig Mine lade, som om han i de Handlendes Forstand og Lidenskaber havde fundet Nøgelen til de Begivenheder, om hvilke de tit aldrig drømte, eller ogsaa under Sandhedskærligheds Maske erklære Alt for Digt, som ei kunde bekræftes med vederhæftige Øievidners Underskrift. Det Sidste kalder Man historisk Kritik, og som Lettroenheds Modgift er Tvivl i et vist Maal, formedelst Menneskenes Lyvelyst, et nødvendigt Onde; men hvor grændseløs Tvivlesygen maa blive i et Hjerte, der ei vil tro Jesus, er begribeligt. 
For Saadanne bliver hvert Folks ældre Historie idel Tant og selv det Troværdigste, naar det ei er tilpas, forkastes som Digt (330).

En passage som denne forklarer tydeligt, hvorfor Molbech måtte bryde med sin nu bibelkristne ungdomsven. Grundtvig fortsætter endda med, at dette uvæsen satte Kant en stopper for ved i sin erkendelseslære at tvivle på en filosofi bygget alene på udvortes erfaringer, dog med indrømmelse af, at han derved hverken kunne bekræfte eller benægte nogen åbenbaring "udenfor sig" selv (331). ${ }^{83}$

Chateaubriand (1768-1848) kæmpede midt i en gudløs Napoleonstid til kristendommens forsvar (i Génie du christianisme, 1802), men stred for den katolske kult som "den fuldkomneste Mythologi" (344), og det var "at salve den til Jordefærd". Når et folk bliver vantro og har overvundet sin skræk og ærbødighed for kristendommen, "leger Man med den", moraliserer Grundtvig. Italiens "mere spillende og klangfulde, end aandelige Poesi opløste sig hos Metastas[io] endelig ganske i Musik", og dramatikeren Vittorio Alfieri (1749-1803) blev samtidig regnet for "at være en Digter, fordi han i alvorlige Ord talte om Fædrenes Kraft og Manddom".

Engelsk digtning omkring $1800^{84}$ er ligesom engelsk tro en "livløs Skygge" (346) med uld og sukkerrør som emner for episke digte. ${ }^{85}$ Samtidig ses nogle bedrøveligt vildfarne filosoffer i Tyskland. J.G. Fichte (1762-1814) nærmede sig ellers kristendommen med sin jeglære i 1794, men blev nærmest sværmerisk pietist (hvis selvforløsning ligner katolsk gerningsretfærdighed). Fr. Schelling (1775-1854) gjorde med sin naturfilosofi kristendommen til en mytologi, men den kunne dog være et gæringsmiddel og berede ægte kristendoms tilbagekomst.

Nedsættende behandles de tyske romantiske digtere Ludwig Tieck, Novalis (Friedrich von Hardenberg) og Zacharias Werner efter formlen 'Først herlige toner, så lutter bristende strenge'. Kriterierne veksler dog. Tieck (1773-1853) skrev sig hæs i eventyr (i årene 1797-1804) og forstummede, ${ }^{86}$ Novalis (1772-1801) gik i romanen Heinrich von Ofterdingen

${ }^{83}$ Ifølge Rettelser (US II, 409) bygger Grundtvigs karakteristik af Kant udelukkende på hans bog Religion, innerhalb der Grenzen der blossen Vernunft, 1793.

${ }^{84}$ I pjecen om H.C. Ørsted, Imod den lille Anklager, bekender Grundtvig dog ligeud, at han aldrig har læst noget som helst af Robert Southey (stavet Southley!), Lord Byron eller Walter Scott (Grundtvig 1815a, 180-181).

${ }^{85}$ Dette gælder waliseren John Dyer (1699-1757) med The Fleece. A Poem, 1757, og skotten James Grainger (ca. 1721-66) med The Sugar Cane: A Poem, 1764. Grainger ønsker sig i optakten til sin 1. Bog inspiration fra Hesiod, Vergil og Ovid og nævner i samme åndedrag "pastoral Dyer" (v. 12). Han må således nok have læst denne nære forgænger med hyrdeliv som speciale. Tak til S.A.J. Bradley for identifikationen af Dyer.

${ }^{86}$ Tieck skrev dog fra 1820'rne en anselig række noveller, inden han i 1840 indstillede forfatterskabet (og han døde først som 80-årig i 1853). 
(posthumt 1802) op i “Allegoriens Dunstkreds" (353), ${ }^{87}$ og Werner (1768-1823) ræddedes for sine egne spøgelsessyner i dramaer 1803, 1807 og 1808 om døende tempelherrer, den levende Luther $^{88}$ og den djævelske Attila og endte som katolik.

Den "store Læseverden" (355) forgiftes og forkæles dagligt "af liderlige Eventyr om Tyve og Skelmer, som dog skal have været skikkelige Folk, af Romaner om Elskeleg, ved Skuespil af samme, af Rænker og Usselhed". Grundtvig regner åbenbart dette for fælleseuropæisk og ikke nationsbestemt. Videre handler såvel almueoplysning som kirkeog skolegang mest "med mange Ord" om "legemlig Dont og unyttig Kundskab, snart barnagtig og snart høitravende". Grundtvig tilføjer dog: "Saa er det ei overalt, men saa er det mangensteds, og som dødt Kød æder det Onde om sig i Folket” (jf. 2 Tim 2,17).

Sverige er stadig poesiforladt, men løgne og fantasterier trivedes hos dets anerkendte historikere:

Ingen Digtere fremstode, uden Man dertil vil regne Rudbek og hans Jævninge [ligemoend], som funde [fandt] Paradiset i deres Hjem, og udsmykkede de ældste, aldeles mørke Tider med de underligste [utroligste] Eventyr. ${ }^{89} \mathrm{Al}$ islandsk Skrift anmassede de sig, og skændte paa Danmarks Saxo, som en ublu Løgner, uden at eie et Blad af deres Eget, som kunde modsige ham (356).

Olof von Dalin (1708-63) gjaldt for en stor digter, men var dog ikke mere end "en vittig Versemager". Hans Sverigeshistorie 1747-62 roses "med Rette for den livlige Fremstilling", men er hverken troværdig eller fuldstændig. Man har kaldt svenskerne for

Nordens Franskmænd, og vel ei urettelig, thi ligesom den nordiske Alvor skinner igennem deres aandelige Syssel, saaledes kundgør den franske Jordiskhed sig i Aandens Retning paa det i Hverdagslivet Nyttige, i Mangel paa dyb Tænkning over det Evige og i Betragtning af Poesien som Veltalenhed og Morskabsleg. Adolfs Søn Gustav den Tredie øvede selv Digtekonsten paa saadan Viis og havde adskillige Medbeilere, blandt hvilke Leopold $^{90}$ og Kellgren have faaet Navnkundighed (356).

I Rettelserne får Grundtvig med, at svenskerne i "den sidste Tid" (410) synes at skulle bevæges af en åndelig gæring ved at oversætte digte af

87 "Dunstkreds" betyder 'atmosfære', men denne germanisme bruges i reglen i nedsættende eller afstandtagende sammenhæng på dansk.

${ }^{88}$ Under sin rekonvalescens i foråret 1811 havde Grundtvig forsøgsvis oversat 243 verslinjer af Werners Luther-drama Die Weihe der Kraft (utrykt, Fasc. 386.68).

${ }^{89}$ Jf. Olof Rudbeck: Atlantica, I-IV, 1679-1702, bl.a. hudflettet af Holberg i hans epistel 193, 1750.

${ }^{90}$ Ifølge en boghandlerregning købte Grundtvig 29. november 1809 C.G. Leopolds skrifter (Fasc. 521.1). 
Oehlenschläger. Det fnyser de gamle svenske frankofiler fra Gustav III's tid ganske vist over, fordi danskerens "Poesi skal søges i Marven og ikke i glatte Been og en konstig sminket Hud". ${ }^{91}$ Unge som især P.D.A. Atterbom (1790-1855) prøver på "at digte efter den ny tydske og danske Vis", men det er at frygte, at de mest løber efter naturfilosofiske "Løgtemænd" - et begreb, der på denne tid hos Grundtvig henviser til Schellings identitetstænkning. ${ }^{92}$ At svensk romantik ikke stammer fra læsning af Oehlenschläger, ville Hammarsköld have fortalt Grundtvig i et privatbrev, der blev nedfældet i $1814 \mathrm{og}$ dog ikke afsendt; en anderledes tekst blev afsendt 26. maj 1821, som Grundtvig gav et besindigt svar på (BG II, 28-32, jf. Borup 1956, 129-141).

Herfra og VK 1812 ud lader Grundtvig specifikt den hjemlige litteraturs historie dominere. Under den nyindførte danske enevælde bør bondesønnen og præsten Peder Syvs ret forgæves kamp for det danske sprog op mod 1700 huskes, men hans lidt yngre kollega Jørgen Sorterup (16621723) var "halv undseelig" ved i "kostelige Viser" (Nye Helte-Sange, 1716) at lovsynge danske søsejre i Store Nordiske Krig (US II, 360).

Den danske litteraturs fader i nyere tid, Ludvig Holberg (16841754), er det et stort problem for Grundtvig at behandle nogenlunde fair, og hans umage er særdeles synlig. Modsat Hans Egede, som 1721-36 missionerede evangelisk på Grønland, kom Holberg med et andet og i manges øjne bedre evangelium. Det blev "gladelig annammet i alle Nørrelande, men spaaede ei Godt om Kraft og Kristendom" (361). Positivt medvirkede det dog til at svække den gysen, som kunne have fremmet væksten af den importerede Halle-pietisme. "Holberg blev Folkets Mand, som sjelden Nogen, sagtens kom det meest deraf, at han talte hvad Man gierne vilde høre" (362) ${ }^{93}$ Hans saglige værker kunne måske endda gå an, men hans komiske digtning viser alt bagvendt, bortkyser alvor, snerter dårligheder, indlægger vittigheder. Peder Paars og komedierne gør nar ad fædrenes fromhedsliv og traditionelle digtning. Grundtvig illustrerer dette med en række flabede udsagn fra Paars, dog uden hensyntagen til

\footnotetext{
${ }^{91}$ Den svenske litterat Lorenzo Hammarsköld (1785-1827) havde i sit tidsskrift Lyceum, 1. hefte fra september 1811, anmeldt Oehlenschlägers Poetiske Skrifter, I-II, 1805, og Nordiske Digte, 1807, positivt, men med nedprioritering af hans nordiske emner (Preisz 1958, 47-49). Atterbom skrev i marts 1811 til Hammarsköld, at han med fryd har læst Oehlenschlägers novelle "Aly og Gulhyndy" i Digtninger, I, 1811, og at han har lyst at oversætte den (Preisz 1968, 468).

${ }^{92}$ I det polemiske svarskrift Krønikens Gienmoele, 1813, 32-50, skildrede Grundtvig udførligere sit mellemværende med Schelling og hans tyske skole.

${ }^{93}$ Leflen for publikum dadles lidt senere også hos Jens Baggesen (US II, 374375). Det er en last, som digteren Grundtvig ikke selv kan anklages for.
} 
Holbergs relativerende fiktive sammenhænge. ${ }^{94}$ Holbergs letsind smittede af på læserne, "thi til Alt havde Man et Sprog [et fyndord; et smart svar], og var vis paa de Leendes Medhold" (363). Holberg var en "Nordens Voltære" (fremhævelsen er Grundtvigs), men så meget bedre end Sydens rigtige Voltaire, "at det hartad er Synd at nævne ham saa". Grundtvig vrider sig ordentlig. Holberg kan undskyldes på flere måder. Han levede i en fordærvet tid (oplysningen), og mange af hans skrifter rammer misbrugt kristendom og lærdom. Han vakte faktisk "den indslumrede Læselyst" og banede vej for en offentlig tale til folkets oplysning og forbedring. Således, slutter Grundtvig, udrustede Holberg sit folk "med kraftige Vaaben mod den hyklede Andagt og Gudsfrygt, som endnu i hans Dage kom hyppig tilsyne". Var han ikke en videre god kristen, var han heller ikke pietist, endsige en spotter af religion. ${ }^{95}$

Den følgende skildring af pietismen er forbløffende ved ikke at nævne H.A. Brorson, heller ikke i Rettelser. ${ }^{96}$ Erik Pontoppidans såkaldte Slotssalmebog, Den Nye Psalme-Bog, 1740, med sine 92 Brorson-salmer er også uomtalt. Dette tal er reduceret til 53 i Guldbergs salmebog, 1783, hvis restoplag gik til grunde under Københavns brand i 1795. Dens efterfølger blev Evangelisk-kristelig Psalmebog, 1798, med kun 21 Brorson-tekster. ${ }^{97}$ Brorsons Troens rare Klenodie og Svane-Sang blev først i 1830 genoptrykt i helhed. ${ }^{98}$

Under Frederik V kom alt det letsindige franske oplysningsvæsen igen (medregnet genåbningen af Holbergs skueplads i København 1748). Heldigvis opstod der et tysk modparti til dette med F.G. Klopstocks harpespil, og samtidig gav J.S. Sneedorff på det Holbergske Akademi i Sorø i sit danske tidsskrift Den patriotiske Tilskuer, 1761-63, "den jordiske Tankegang en alvorligere Retning" (365). Trønderen C.B. Tullin sang om fromme gudelige emner, "men Tonerne vare for svage til at indtrænge i de Flestes Øren" (367), og han døde allerede

${ }^{94}$ De betænkelige vitser fra Paars gælder Peder Ruus' ytring om evigheden i 1. Bog, 1. Sang, v. 243-244, Anholtboens tale om at nære sig kristeligt af vrag, 1. Bog, 2. Sang, v. 48, Per Degns regel om ikke at saligprise en død før i hans grav, 1. Bog, 2. Sang, v. 350, og tyske Jochums oplæste tysk om den korte fart herfra til Paradis, sådan som det blev misforstået af Christen Storks kone, 3. Bog, 1. Sang, v. 272.

${ }^{95}$ Grundtvigs syn på Holbergs fejl er således skærpet siden det venligere portræt ved hans grav i digtet "Sorø Kirke" i digtsamlingen Nytaarsnat eller Blik paa Kristendom og Historie (Grundtvig 1811a, 61-62 og 64-65).

${ }^{96}$ Jf. Sørensen 1966, 39-67.

${ }^{97}$ Grundtvig anskaffede sig først Evangelisk-kristelig Psalmebog 18. december 1811 (boghandlerregning i Fasc. 521.2).

${ }^{98}$ Udgiveren var den grundtvigianske sognepræst J.A.L. Holm (1799-1861) i Holsteinborg, og hans udgave nåede efterhånden mindst 9 oplag (1880). 
som 37-årig i 1765. Året efter døde kongen og blev besunget af den nye skjald Ewald, skænket til Danmark af Gud. Ewald gemmer Grundtvig dog til lidt senere (378-379).

Her indføjer Rettelser et længere afsnit om videnskabelige selskaber, samfund og akademier. Det er egentlig et sygdoms- og dødstegn, når sådanne opstår og trives, "et sanddru Vidnesbyrd om Videnskabelighedens Forfald" (410). Efter historiske lynglimt tilbage til det kongelige museum i Alexandria (ca. $280 \mathrm{f}$. Kr.) og til Konstantinopel i det 8. århundrede finder Grundtvig, at de trods alt gør nogen almindelig nytte. De opretholder "et Slags Agtelse for Videnskaberne" (411), de udgør "en lærd Ridderorden", og de ansporer adskillige, der ikke bryder sig stort om åndelige værdier, til "en Flid der beriger Videnskabernes Tøihus". Herefter nævnes Det Kongelige Danske Videnskabernes Selskab fra 1742, Det norske Videnskabernes Selskab (i Trondhjem) fra 1760 og Det Skandinaviske Litteraturselskab fra 1796 (stiftet i København af C.H. Pram, Rasmus Nyerup, Jens Baggesen og J.K. Høst).

Tilbage i sin egentlige fremstilling nævner Grundtvig universitetsprofessor Jacob Baden (1735-1804) som flittig kritiker i litterære periodica 1767-1801: "I henved 30 Aar dømte han Skrifter, ei altid ret, men altid som en Mand, han havde i Grunden et klart Øie for det Store og Rigtige, Tidens Strøm formaaede ei at rokke ham et Straasbred fra hans Stade" (369). Det ligner et skjult selvportræt.

Rettelser har et længere indskud om danske tidsskrifter i det 18. århundrede, med en række karakteristikker af endnu levende mænd. Tidsskriftgenren kommer fra Frankrig og England, hvor den læses af sky for åndelige alvorstanker og af skræk for tykke bøger (Bibelen medregnet). Den præsenterer ugentlig eller månedlig "en Blanding af Nyheder, Vers og løselig Tale om Dagens Optrin og Kephest, en kær Skænk” (413), hvorfra uforpligtende samtaleemner kan hentes.

En række af de danske nævnes og bedømmes ultrakort. I det 18. århundrede behøvede Sneedorffs Den patriotiske Tilskuer blot indbindes for at danne en god bog. K.L. Rahbeks Minerva, 1785-1808, ${ }^{99}$ hævdede sin dronningerang, talte med næsten alle danske tunger, der har været hørt siden, og var for alvorligt til kådhed. Og Iris (hvor lægen og litteraten J.C. Tode førte sig frem 1791-95) indeholdt mangt et kristeligt ord. De (Kjøbenhavnske) Laerde Efterretninger, redigeret af Nyerup 1790-97 og 1800-04 af P.E. Müller (og fortsat af sidstnævnte som Dansk Litteraturtidende 1805-30) hånede derimod præsterne og hørte til fjenden, men blev dog bekæmpet af den rimelige Iris og Jacob Badens UniversitetsJournal, 1793-1801. Den danske Tilskuer, 1791-1808, ved Rahbek de-

\footnotetext{
${ }^{99}$ Forsinket af det engelske bombardement i september 1807 udkom Ny Minerva for december 1807 først i april 1808, hvorefter tidsskriftet ophørte.
} 
monstrerede desværre, hvorledes dennes skarpsynede kritik efterhånden svækkedes, ${ }^{100}$

i Førstningen var hans Øie ei dertil udygtigt, mangen Daarlighed udspeidede Han, og snertede den følelig med sin fine Svøbe; men jo længere han stod, des stærkere blev Taagen og Stadet sank synlig under ham, indtil Han omsider roste Alt hvad der skyggede paa Parnas fra Fod til Top. Det er tungt at se et vakkert Hoved saaledes gaa under, fordi det ikke vilde i det Rene med sig selv (414).

Dette kan læses som en opremsning af egenskaber, Grundtvig nægter at udvikle hos sig selv. Den gode Baden og den mindre gode Rahbek bedømmes begge på deres ståsted (ved ordene "Stade" og "stod").

Antikristne tidsskrifter er Malte Møllers Repertorium, 1795-97, og Otto Horrebows "Skandskrift” Jesus og Fornuften, 1797-1801. I det 19. århundrede bliver Loerde Efterretninger mest en tidende om litteraturens død. L.N. Fallesens Maanedsskrift for Theologer, 1803-08, tager en mellemvej mellem oplysning og sand kristendom, og dets ophør vidner om præsteskabets søvnighed og middelmådighed. Det i 1811 grundlagte kvartalstidsskrift Theologisk Bibliothek ved Jens Møller "gaaer vexelvis paa alle Veie" (415), men fænger ikke rigtigt. ${ }^{101}$

I sin egentlige tekst konstaterer Grundtvig om salmebogen fra 1778 (også kaldt Købstadssalmebogen eller Birgitte Boyes salmebog), at Ove Høegh-Guldberg og biskop Ludvig Harboe ville omstemme salmetonen i Klopstocksk diktion, fordi den "gemte Kløgt og Sindrighed i høie Ord, og gav Forstanden mere at bestille" (370). En del Kingo blev bevaret til de enfoldige, men mange nye salmer "for de mere Oplyste" kom til (skrevet af "Madam Boie"). Bogen brugtes dog kun i købstæderne og "uden stor Vinding, som var let at gætte, thi naar Andagten vil have Marmortrapper at opklavre paa til Himlen, er det Tegn til, den har mistet sine Vinger, og er kun sit eget dunkle Minde."

Gud greb ind over for dansk åndsliv i sidste halvdel af det 18. århundrede ved at give det "en kristelig Tænker som glemtes, og en kristelig Digter som blev overdøvet" (372). Tænkeren var Tyge Rothe (som Grundtvig lige nåede at genopdage til sin fortale til $V K$ 1812, men ikke

${ }^{100}$ I 1807 havde Baggesen i samtaledigtningen Giengangeren og han selv, eller Baggesen over Baggesen fældet en lignende dom over Rahbeks venneros (Arlaud 1903, 75-78, 82-93 med tilhørende slutnoter). Grundtvig havde i en anmeldelse af Giengangeren tilsluttet sig denne saglige kritik, men lagt afstand til Baggesens personlige persiflage mod Rahbek (Kjøbenhavnske loerde Efterretninger, No. 12, 1810, 187). Baggesens originale tekstsammensætning i bogen fra 1807 er for resten aldrig blevet optrykt.

${ }^{101}$ Det kom dog bedre på gænge, end Grundtvig formodede i 1812, og ophørte først i 1834 efter udgivelsen af i alt 44 bind (med let vekslende serienavne). Ved sin død i 1833 havde Jens Møller selv skrevet omkring hundrede bidrag til det. 
fik fordybet sig i), og digteren var Johannes Ewald, der blev "Røsten i Ørken". ${ }^{102}$

Grundtvigs dom over Ewald er præget af godt kendskab til hans offentliggjorte forfatterskab. Ewald tog Klopstock til sit mønster, men kun fordi de to var åndsbeslægtede i høj tankeflugt. Den forklares ret negativt som en "Stræben efter, i udtænkte Ord at udtale Troens Hemmelighed og ved Opdigtelser udsmykke Kristendommen" (373) og i en længsel efter "de Tider, da Mennesket, enig med sig selv, kun stred med det Onde udenfor sig". Ewald afveg dog, understreger Grundtvig, fra Klopstock ved at have humor og sans for komik. Som "alvorlig Sanger sværmer han vemodig og taareblendet, og hans hellige Begeistring er enten et vildt Spil, eller en Krampetrækning". ${ }^{103}$ Hans indre og ydre liv blev besværligt, men "hvilke herlige Toner klang ei fra Harpen og Sitaren!” I syngespillene Balders Død, 1775, og Fiskerne, 1779, lovsang Ewald kærlighedens henholdsvis bitre og søde smerte, i prosadramaet Rolf Krage, 1770, forenede han manddom og følelse, i sin antikiserende ode "Til Sielen", 1780, "nedtordnede" han den menneskeligt hovmodige forstand. ${ }^{104}$ Selv i verskomedierne Harlequin Patriot, 1772, og De brutale Klappere, 1771, skinnede "Alvor og høiere Øiemed igennem Lattersløret". Det passede ikke samtiden, der hellere ville håne hans (for) høje patos.

Norske Selskab 1772 ff. domineredes af franskhed og fransk smag, lo ad Ewalds stilexcesser og "spottede alt ægte Skjaldskab". Johan Vibe, den danske Anakreon, var dog mere beruset end "begeistret". Wessels parodikomedie Kierlighed uden Strømper, 1772, var "et Mesterværk i sit Slags" - med et citat fra Steffens' utrykte Goethe-forelæsninger 1803. ${ }^{105}$ Skønt Wessel sigtede mod "al egenlig Poesi og aandeligt Heltesind", nedrev han "lysteligt" især de franske sørgespil, "hvori Intet skeer og Intet forgaar, men Heltene dø, naar de har sagt, hvad de vidste". Netop dette hjalp til "at styre det Uvæsen med tomme Triller,

102 Es 40,3, Matt 3,3. Det er dog næppe rimeligt af Grundtvig at betegne Ewald som en "overdøvet" digter, hverken i dennes levetid eller i eftertiden.

${ }^{103}$ Grundtvig noterer, at "vildt stormede det i hans Inderste", så kun i komik var han "rolig". Det var modsat det billede, Baggesen i Labyrinten, I, 1792, 133-134, havde skitseret af Klopstock i Hamburg som en så stærkt neddæmpet barde, at hans højeste forte ved oplæsning af egen lyrik ikke oversteg almindelige taleres piano, og hans pianissimo var uhørligt.

${ }^{104}$ Grundtvig nævner ikke Ewalds storstilede syndefaldsdrama Adam og Ewa, 1769, som han antagelig har kendt $i$ det mindste fra lige før julekrisen 1810 (Lundgreen-Nielsen 1980, 390). Ewalds frit tilsatte visioner om den lysende helt Kristus som dødsenglens overmand og (i kerubernes slutsang) om Guds søn som frelser og forløser har måske været Grundtvig for dristige i forhold til 1. Mosebog - med andre ord for Klopstocksk udtænkte?

105 Jf. $M M 1877,276$. 
høitravende Snak og latterlig Flæben, som begyndte slemt at drives" (373374), endog i de mere nordiske hoveders digte. Trønderen J. Nordahl Brun (1745-1816) med sørgespillet Einer Tambeskielver, 1772, og guldbrandsdølen Edvard Storm (1749-94) med "Zinclars Vise" fra ca. 1781 fremstod "nordiske og kristelige i Sind" (374) som genopdagere af det ægte gamle Norge, ${ }^{106}$ men "begge stræbte forgæves at henrykkes af Bibel og Kristendom". Grundtvig kan tænke på Bruns oversete bibelske epos Jonathan, 1796, og hans salmer og på Storms åndelige sange. Det var eksempler på Grundtvigs kortfattede og dog nuancerede domme.

I stedet for det danmarkshistoriske kupår 1784 - kronprins Frederiks reelle magtovertagelse fra den sindslidende fader - og den følgende reformperiode før den franske 1789-revolution markerer Grundtvig året 1783 som begyndelsen til en dansk nutid, "en ny Afdeling i det sidste Tidsrum" (374).

Alene dette år er "rigt paa mærkelige [bemcerkelsesvcerdige] Tildragelser", nemlig, at N.E. Balle bliver Sjællands bisp, og at Suhm udgiver Historie af Danmark I, Christian Bastholm sin dogmatik Den christelige Religions Hoved-Laerdomme, Jens Baggesen den gennemrimede Comiske Fortcellinger (hans debutbog) ${ }^{107}$ og T.C. Bruun den dristige digtsamling Mine Frie-Timer; desuden fuldføres Jens Worms forfatterleksikon, IIII. ${ }^{108}$ Ydermere er - hvad Grundtvig ikke nævner - 1783 også 300året for Luthers fødsel og det år, hvor han selv kom til verden i Udby.

Og nu videre med Grundtvigs rundtur. Sjællænderen T.C. Bruun (1750-1834) får en usædvanlig hård medfart: han har lige fra 1783

besudlet mange Blade med ugudelig og liderligt Skemt, og skammelig misbrugt Vittighed og velklingende Vers til at forgifte Troens og Dydens Kilde i sit hellige Udspring. Mangen Mand maa bande den søde Gift han som Yngling indsugede af de onde Blomster, og endnu, paa sine gamle Dage, vedbliver den Forblindede at bygge sig et Gravsted af Uteerlighed, ja han vil indbilde sine Landsmænd, at det er et godt Træ, som bærer de raadne Frugter (374).

Grundtvig havde dog selv 1801-03 fordybet sig ukritisk i Bruuns versificerede uartigheder. ${ }^{109}$

\footnotetext{
${ }^{106}$ Grundtvig kalder dem “Jothernes Talsmænd”; bl.a. i P.F. Suhms forfatterskab var joterne Nordens ældste indbyggere før de germanske goter.

${ }^{107}$ Denne bog udkom dog først i 1785, så her husker Grundtvig forkert.

${ }^{108}$ Det bibliografiske hovedværk Forsøg til et Lexicon over danske, norske og islandske larde Mcend udkom i 3 bind 1771-84, det sidste med god bistand fra nevøen Oluf Worm.

${ }^{109}$ I højsommeren 1812 søgte Grundtvig forgæves at standse en samlet genudgivelse af Bruuns digtning (Lundgreen-Nielsen 1980, 525). Se også her note 14.
} 
Jens Baggesen (1764-1826) havde Grundtvig publiceret tre æstetiske afhandlinger om i Laerde Efterretninger, 1809-10 ${ }^{110}$ - alle i øvrigt uoptrykte - men den samlede behandling, de lagde op til, standsedes antagelig af Grundtvigs åndelige forvandling i julekrisen 1810. Nu i 1812 fremhæves Baggesen som en sjællænder med et "opvakt Hoved med spillende Vittighed, let Nemme, løs Følelse og et sjeldent Herredømme over Tungemaalet" (374). De omhyggeligt udsøgte ord til generel karakteristik er ouverturen til en tæt gennemspilning af Baggesens digteriske evner og poetiske emner.

Først var Baggesen med komiske (vers)fortællinger en elev af J.H. Wessel, men "øiensynligt var det, at han gjorde Vold paa sit halve Selv, og lidt mere kræsne Ganer vilde have fundet hans fleste Retter vandede og flaue" (374). Grundtvig borer ned $i$ hans psyke ved samtidig at undskylde ham med, at publikum var ham for venligt stemt. Dette blev fatalt, for det gjorde ham afhængig: "Bifald og Yndest vilde han vinde, hvad det saa end skulde koste; han fik og de dyrekøbte Sæbebobler, da han, med mere Hensyn paa sine Anlæg og sin Tænkemaade kaarede Vieland til Mønster" (374-375). Det hentyder til hans Wieland-inspirerede librettoer til de nationale operaer Holger Danske, 1789, og Erik Eiegod, 1798 (skr. 1789), begge med musik af F.L.Æ. Kunzen. Herefter gennemgås Baggesens væsentligste titler. "Sin egen aandelige Skikkelse har han i Labyrinten [1792-93] eftermalet med blændende Farver" (375), og i "Kallundborgs Krønike" (anonymt i Minerva 1786) er hans latter ægte "og i visse Maader" - nemlig nok satiren over censur - rosværdig. I sine rimbreve har han som en genkommen normanner belejret Paris og "erobret et Normandi", altså fordansket denne horatsiske genre efter den franske klassicismes mønster (Boileau). I det hartad mageløse gengangerdigt (udsendt i marts 1807) spotter han bittert sig selv og sine ligesindede. Temaet her er "aabenbar Kærlighedens Forlis", men hans bodsvandring er underlig ligesom engang flagellanternes: han "mindedes visselig af sin gode Aand om hvad han burde være, men hans Bedrøvelse var mest den efter Verden" (375). ${ }^{111}$ I de episke digte "Emma" (i Minerva 178687) og Parthenäis (1803, skr. på tysk) anes kærlighedens "rene Ild" næppe, og når han sang om Gud, "hyllede han sig i en Dunstkreds af høitravende Ord og kolde Billeder". Ved Grundtvigs ordvalg kan Baggesens kristelige lyrik ses som en parallel til de "glimrende men kolde Lignelser" (208) hos romerske digtere under Augustus.

${ }^{110}$ Den i 1810 er kun signeret "G.", men vedkendt af Grundtvig i 1818 (US III, 611). Ifølge en boghandlerregning købte Grundtvig Baggesens genganger-digtning 14. juli 1808 (Fasc. 521.1).

${ }^{111}$ Det sidste udtryk betyder, at Baggesens sorg mest skyldtes en uopfyldt længsel efter denne verdens glæder. 
Baggesen var en skjald skabt som en "herlig Fugl" (375), der kunne have "tonet saa liflig i Danmarks Skove, til Vederkvægelse for Aander og Hjerter, mens Seklerne skride; men han vilde heller med farvede Vinger flagre i Kreds om Jordens Blomster”, og det må Grundtvigs hjerte bløde ved at se. I 1812, da Baggesen er fyldt 48, konstaterer Grundtvig, at hans sommer nu er forbi, hans farveskin er blegnet og fjerene i de sænkede vinger grånede. Ligesom Goethe har han således forfejlet sit kald. Men vil han endnu inden vinter (alderdom og død) "med den levnede Kraft (...) alvorligen stræbe fra Jord", skulle man høre en "Svanesang" (afskeds-, døds- og sejrssang) til gru for Guds fjender og til glæde for Baggesens venner. Grundtvigs billedsprog flakser fra sangfugle i skovens dyb over brogede sommerfugle på en blomstereng frem til hvide sangsvaner. Dermed slipper Grundtvig indtil videre gåden Baggesen - uløst. ${ }^{112}$

Det 18. århundredes klubliv, som er befolket med "patriotiske Harlekiner" (en Ewald-kategori!), får en negativ skildring som steder, hvor man åd, drak, musicerede, dansede, spillede kort, snakkede - "uden videre Sammenhæng". ${ }^{113}$ I revolutionsårene bredte en begejstring sig dog netop i klubberne og rev digterne med:

Baggesen svimlede paa Alperne ved Hyrdefløiten, Tordnen over Gothard og Lyden af Riqvettis udødelige Navn; Reins vemodige Toner hendøde mellem Fjeldene, Pram forvildede sig i Luften med Stærkodder, og Spot med Konger i Himlen og paa Jorden blev Visernes Omkvæd, men Digter og Visemager vare nu tvende Ord i selvsamme Mening (378). ${ }^{114}$

112 Det fremgår af et brev fra digterinden Juliane Marie Jessen 24. februar 1817, at Baggesen og Grundtvig på denne tid trods udveksling af offentliggjorte rimbreve 1815-16 (i den såkaldte Valhalla-leg) endnu ikke har truffet hinanden personligt ( $B G$ I, 454-455). I 1817 boede de endda begge i den fra 1805 ff. anlagte Kronprinsessegade med udsigt til Rosenborg Slot, Baggesen i nr. 390, Grundtvig på 3. sal i nr. 402 (nu nr. 44) (Johansen 1960, 63).

${ }^{113}$ Beskrivelsen ligner Grundtvigs egen senere erindring om sin åndløse tid som stud. theol. i København (dog musik og dans undtaget).

${ }^{114}$ Baggesen kan siges at spille på hyrdefløjte i sit idylliske heksameter-epos (på tysk) Parthenäis, St. Gottard og Riquetti hentyder til to oder af ham fra 1791 (til en alpebjergtop, han besteg i 1789, og til Mirabeaus død). Nordmanden Jonas Rein tog i Nyeste Digte, 1810, afsked med sin digtergerning (i et forord dateret 1806) for at være præst i sit fødeland. Pram skildrede det nordisk-mytologiske trylleskib Skibladner, der sejlede lige så hurtigt over træ- og bjergtoppe som over bølger, $\mathrm{i}$ 13. sang af sit store epos Stcerkodder, 1785 (hvormed han dog i almindelighed overanstrengte sine digterevner). Spot med konger findes bl.a. i P.A. Heibergs viser (dog ikke vendt imod den dansk-norske monark). Grundtvigs billedsprog synes at mistænkeliggøre følelser fremkaldt af bjerge og bogstavelig himmelstræben. Hans verber 'svimle; hendø; forvilde' peger til det, som savner styring. 
Malthe Conrad Bruun (1775-1826) og P.A. Heiberg (1758-1841) angav fællestonen, nemlig "en Surren, som af en sværmende Biflok, der kaad og doven stikker Enhver, vil bade sig i de veltede Kubers Honning, men ingen virke [producere]." Scenen med de uansvarlige bier er dog nok et tvivlsomt stykke naturhistorie. ${ }^{115}$

Imidlertid måtte både jyden Malthe Bruun - "et ungt Menneske med et varmt Hoved, noget digterisk Anlæg og stor Lyst til at roses i Klubber og glimre i en Folkeforsamling", ophavsmand til et forfatterskab uden "alvorlig Eftertanke" (378) - og sjællænderen P.A. Heiberg landsforvises for kådhed og foragt mod regeringen. Heiberg havde "megen Vittighed, skarp Forstand, alvorligt Had til al Undertrykkelse", men hans oprindeligt kærlige hjerte blev ved ydre modgang "fuldt af Bitterhed og Mistanke", og frihedsideerne forvildede ham. Heiberg var ikke kristen, skønt han til sin ære heller aldrig angreb kristendommen. Hans vrede imod tyskere i Danmark og imod den danske adel var ilde anbragt, for det var folket, han skulle have lastet, mener Grundtvig - "Tidens Vanart i det Hele" (379). P.A. Heibergs forfatterskab behandles ikke.

Evangelisk-kristelig Psalmebog, 1798, burde være udgivet af den eneste navnkundige digter i revolutionsårtiet, der havde en vis sans for gamle salmer, nemlig Thomas Thaarup (1749-1821). Med "digterisk Anlæg" (381) forenede han "en gudelig og hjertelig Stemning, men neppe var det om de kristelige Troessandheder han sang, og han har ei villet kendes ved sine Sange, saaledes som de udkom". ${ }^{116}$ Uden Thaarup må Grundtvig konstatere, at den nye salmebog desværre kom til at bestå af salmer rimet sammen "i kolde Billeder og høitravende Ord" af upoetiske mænd. ${ }^{117}$ Ikke én af Luthers eller Kingos står uantastet, og ingen af højtidssalmerne er anskueligt fortalt, Djævel og Helvede er udeladt, og mange vandede rim priser dyd og gerninger. Bibelsk enfoldighed mangler, og Kingos salmer "behøvede en med Ærbødighed ændrende Haand". Alligevel må den drivende kraft i sagen, biskop N.E. Balle - Grundtvigs og Steffens' onkel - undskyldes med, at en bedre salmebog ikke ville

115 Ordene "kaad" og "doven" synes at modsige hinanden, men kan betyde henholdsvis 'ansvarsløst overmodig eller ustyret vild' og 'med ulyst til at arbejde'. Nøgleordet i passagen er nok "sværmende", som både verdsligt og religiøst er negativt i Grundtvigs sprog. Ellers var han da glad for at iagttage bier, som han senere kalder "disse rare Fluer, som jeg fra min Barndom har elsket lige saa meget, som jeg hadede de andre" (MM 1877, 442-443).

${ }^{116}$ Hentydningen er lidt usikker. I en forerindring til en trykt passionssang i 1792 meddelte Thaarup, at en plan om at skrive en cyklus af kantater til alle kirkelige højtider måtte opgives på grund af hans tyngende embedspligter som lærer i historie og litteratur ved Søkadetakademiet (Andersen 1934, 909-910 og 891). ${ }^{117}$ Igen minder Grundtvigs ordvalg om de i hans øjne flove romerske poeter under Augustus (US II, 208-209). 
have nyttet med den type præster og lærere, der skulle bruge den i deres praksis. Igen tidens vanart ...

I rettelsesdelen af $V K 1812$ opstiller Grundtvig idealet for en salme. I stedet for at være endnu en tør paragraf i systemet skal den

i yndige, bevægelige Toner udsjunge det barnlige, broderlige Sindelag, den skal henrykt kvæde om Faderens og Jesu Kristi uudgrundelige Kærlighed, og male et sanddru, levende Billede af den efter Skriftens hellige Historie, især Jesu Levnet (416).

Den, der tyer til 1798-salmebogen for "at opvarmes af inderlig brændende Kærlighed til sin Gud og Frelser, til Venner og Fiender", mærker tydeligt et savn, som ikke kan bortforklares. Dette svarer til, hvad Grundtvig skrev om den historisk fortællende salme i indledningen til førstetrykket af barnesangen "Deilig er den Himmel blaa" allerede i Rahbeks tidsskrift Sandsigeren fra påsken 1811 (US II, 77-79). En salme skal skrives på oplevelseskvalitet og kunne videregive denne.

I Rettelser har Grundtvig også tilføjet afsnit om to digtere fra samme årti. Itzehoeren L.C. Sander (1756-1819), en elev af Basedow, skrev et af de første danske sørgespil, Niels Ebbesen, 1797, men kun ud fra "middelmaadige Anlæg og Hovmod over al Maade" (417). Stykket var "ret kløgtig udtænkt og sammensat, men Poesi er der kun lidt af, og endnu mindre Historie" (418). Og Ole Johan Samsøe (1759-96), Rahbeks nærmeste ungdomsven, havde et sind med dybe længsler, men svækkedes af sin slappende følsomhed, opnåede ingen livfuld beskuelse og døde bogstavelig talt sammen med hovedpersonen i sit historiske sørgespil Dyveke, $1796 .^{118}$

Grundtvig slutter sin periodegennemgang med det 18. århundredes seneste fastsættelse af betingelser for trykkefrihed: "Fra den Stund Trykkeloven udgik [ $i$ den skcerpede stand 1799], blev der tyst paa den aandelige Børs, og Man sukkede over dens Palladium [vern], uden at ville indse, at det Ilion, Loven kunde og vilde omstyrte, maatte være bygt af Ugudelighed og Uteerlighed, Æreskænderi og Oprørstale" (382). Danmark var blevet et stærkt degenereret Troja med tvivlsomme helte.

Hermed er banen ryddet, så Grundtvig endelig kan nå frem til det fornyende dansklitterære morgengry i det 19. århundredes første tiår.

Om sin fætter Henrich Steffens' indsats i forelæsningerne ved Københavns Universitet fra november 1802 til sommeren 1804 udtaler Grundtvig som øjenvidne: "Faa forstode noget Sammenhængende af hans, med mange Konstord udstafferede Tale" (384). Men det blev

118 Samsøe døde uventet 24. januar 1796 efter nogle ugers sygdom, altså tæt på urpremieren 30. januar (festforestillingen for kongens fødselsdag), hvor publikum for første gang i slutscenen overværede hovedpersonen Dyvekes død. Den tredje opførelse, hvis indtægter tilfaldt forfatteren, blev så i stedet en mindehøjtidelighed for ham. Stykket er i alt spillet 77 gange. 
noteret, at han hånede oplysningstiden og de to tyske modeforfattere, dramatikeren August Kotzebue (1761-1819) og romanskribenten August Lafontaine (1758-1831), og talte om Goethe og Shakespeare som meget større navne. Dem havde i hvert fald Grundtvig dengang aldrig hørt navnene på. Steffens fik lige to år i København, kom i juni 1802 og svandt som "et Luftsyn" (en meteor), da han midt i 1804 fik et professorat i Halle. Det var fordelagtigt, mener Grundtvig nu, for ellers havde han nok "forvirret, om ei forrykket mange Hjerner". Han vakte kun til "Eftertanke", men "mangt et Frøkorn, som han udstrødte, er vist under Guds Velsignelse i Stilhed opvoxet til at bære god Frugt". Grundtvig var klar over, at Steffens delte nogle af Schellings meninger, men fandt, at han nærede langt mere uskrømtet ærbødighed for kristendommen. ${ }^{119}$

Først og fremmest påvirkede Steffens den unge Adam Oehlenschläger (1779-1850), der dog i forvejen dels var ved at tilslutte sig Johs. Ewald, dels var begyndt at gendigte nordisk oldtidsstof. Men Grundtvigs personlige forhold til den fire år ældre poetiske kollega var ikke uproblematisk. I en samtale med Oehlenschläger i 1811, der fortsatte $i$ en halvpinlig brevveksling med ham fra Udby 23.-28. juni 1812, havde Grundvig forsøgt at sondere hans kristentro, men var blevet pure afvist med en regulær opsigelse af kontakt fra Oehlenschlägers side ( $B G \mathrm{I}$, 78-83). Først 17 år senere, den 28. september 1829, talte Oehlenschläger ved et tilfældigt møde på gaden igen til og med Grundtvig (Albeck 1979, I, 434). Et nærmere venskab blev aldrig etableret, og de to forblev antageligt Des. ${ }^{120}$

Ikke desto mindre er det efter Oehlenschägers hidsige, men privat holdte opgør med Steffens og hans væsen i årene 1805-07 Grundtvig, der bliver ved med at kredse om det store gennembrud af ny digtning, ny filosofi og ny kunst ved århundredskiftet som noget epokalt. ${ }^{121}$ Han havde jo selv boet midt i København i årene 1802-04 og mærket atmo-

${ }^{119}$ Dette fremgår dog ikke af 1803-trykket af de 9 indledningsforelæsninger fra 1802, så enten har Steffens gjort sin forelæste tekst mere videnskabelig og mindre forkyndende til trykket, eller også gælder udtalelsen snarere de ikke-nedskrevne og derfor tabte Goethe-forelæsninger fra 1803 (jf. privatoptegnelse af Laurids Engelstoft 25. januar 1804 om Steffens' ortodoksi, Jørgensen 1977, 20-21).

${ }^{120}$ Ved festen for Oehlenschlägers 70-årsdag 14. november 1849 på Den Kongelige Skydebane uden for Vesterport overrakte Grundtvig ham med nogle få hjertelige ord en lykønskning og en laurbærkrans på vegne af de danske kvinder (der ikke var medindbudt). Ved Oehlenschlägers bisættelse 26. januar 1850 holdt J.P. Mynster sørgetalen i Frue Kirke, mens Grundtvig talte ved graven på Frederiksberg Kirkegård (jf. Danskeren III, 1850, 81-96).

${ }^{121}$ I brev af 29. august 1830 understreger Ingemann med rette, at det var Grundtvig, der "stærkest af alle" (Grundtvig 1882, 90) forstod og udtalte sig om Oehlenschlägers førsterang i den nyere danske poesi (romantikken). 
sfæren, ja, uden dybere forbindelse havde han endda hyppigt truffet fætteren privat ved middagsbordet hos deres fælles onkel, professor F.L. Bang.

Epokale markeringer arbejdede Steffens i 1802-forelæsningerne selv med. Han så "et Vendepunkt i den hele Historie" (Kondrup 1996, 133) ved kristendommens opståen, fandt, at "den poetiske Spire var vakt" i nyere tid ved Goethes geni, og syntes, at den "nyere vaagnende Philosophie, lover en herligere Tid" (143). Geniet "gjennembryder alle de Regler, man vil udkaste for det, baner sig og, ved sig, sin hele Tidsalder en egen Vej" (146) og "bryder" derved glansfuld ud af massen (147). Disse brud er netop uventede og ikke rationelt forklarlige. Med andre ord ligner de religiøse undere og omvendelser.

I kølvandet på Steffens var Grundtvig energisk med at se Oehlenschlägers pludselige forvandling i 1802-07 som tegn på nytår og morgengry. Grundtvig analyserer videre på epokeskiftet $\mathrm{i}$ det hjemlige åndsliv i sine Danne-Virke-år, især i et ufuldført og utrykt manuskript fra tylvtefejden i efteråret 1818, hvor han skildrer forholdet mellem fuglekongen Oehlenschläger, fuglefængeren Henrik Steffens og friskytten Jens Baggesen (Fasc. 180.1 og 208.11, jf. Lundgreen-Nielsen 1980, 811-828). ${ }^{12}$

Gennembrudsmodellen accepteres af Oehlenschläger i hans Levnet, I, 1830 (dvs. marts 1831), kap. 12-13; værket var ude på tysk allerede i 1829. Grundtvig skitserer og anerkender videre det nye i sine Mands Minde-forelæsninger 1838 (tr. posthumt i 1877, se fx MM, 268 ff.). Han genserverer begivenheden i mindedigte over dens deltagere, Bertel Thorvaldsen i 1844 (Danskeren I, 1848), Henrich Steffens i Berlingske Tidende 14. marts 1845 og Povel Dons (ved dennes død i 1843) i en digtantologi fra 1867. Også i Kirke-Speil, der holdtes som forelæsninger 1861-63 og tryktes i 1871, mindes Grundtvig "den forskrækkelige Støj” fra Steffens på Elers' Kollegium i 1802 sammen med Nelsons "stærke Kanonade i Kongedybet" året før (US X, 337). ${ }^{123}$

I $V K 1812$ leverer Grundtvig en oversigt over Oehlenschlägers forfatterskab, som er udførligere end ved nogen som helst anden digter i bindet. Hans Digte 1803 "ændsedes kun af Faa og yndedes af Færre" (US II, 385), men lovede stort. Trods den magtfulde formulering med både vokalisk og konsonantisk bogstavrim er Grundtvigs vurdering ikke

\footnotetext{
${ }^{122}$ I VK 1817 taler Grundtvig dog ironisk afstandtagende om de unge tyske (romantiske) digteres "splinterny Tid, som skulde begynde med en Dommedag, men derpaa strax gaae over til et Himmerig” (US III, 719).

123 Romantikkens gennembrud glider ind i dansk litteraturforskning med $\mathrm{Kr}$. Arentzen: Baggesen og Oehlenschläger. Literaturhistorisk Studie. II. Sommeren 1802-1807, 1871, fulgt af to disputatser, Valdemar Vedel: Studier over Guldalderen i dansk Digtning, 1890, og Vilh. Andersen: Guldhornene. Et Bidrag til den danske Romantiks Historie, 1896 (sidstnævnte er videreført i sammes monografi Adam Oehlenschläger. Et Livs Poesi, I. Ungdom, 1899).
} 
rigtig. Bogen høstede ikke imponerede anmeldelser, men fik dog i alt fire, heraf én meget lang og grundig, ${ }^{124}$ og solgte så pænt, at Oehlenschlägers egen forlægger, universitetsboghandler Frederik Brummer, lod fremstille et hemmeligt ekstraoplag på 1500 eksemplarer (med nogle nytilkomne trykfejl). Det oprindelige oplag var vist på 1000 eksemplarer.

Poetiske Skrifter, I-II, 1805, finder Grundtvig er en næsten mageløs "Blomsterkrands" (385), et højdepunkt. ${ }^{125}$ "Hardtad Alt er udrundet af en høi, Meget af en hellig Begeistring, og har sikkerlig virket mere for Kristendommen end alle Tidsalderens apologetiske Skrifter tilsammen", fordi de "herlige Digte maatte vække, hvad de aandede: en kristelig Stemning". Det er virkelig stærke ord fra Grundtvigs pen. Ved fortællingen Vaulundurs Saga bortjager sød enfoldighed læserens beundring for den type højtravende svulst, som ellers gælder for smukt sprog. Og mangt et digt prioriterer tydeligt den barnlige fromheds vinger over "Kundskabens opdyngede Myretuer"; i "henrivende Toner" udlægges det samme i dramaet Aladdin. ${ }^{126}$ "Tidens Vanart og latterlige Hovmod" udstilles i komedien Freias Alter, i digtkredsen "Langelands-Reise", i enkeltdigtet "Morgenvandring" og i de alvorlige sange om "Kristi Livsbillede i den aarlige Natur". Sørgedigtene over billedhuggeren Wiedewelt og botanikeren Martin Wahl er uovertrufne i samtiden. I Kristus-allegorien aner Grundtvig dog en fare for Oehlenschläger: som digter er han kristen, men "Tænkeren var det kun halvt". Det er en "Orm, som nagede den herlige Rose, og vilde, hvis den fik Raaderum, fortære dens herligste Safter" - et Staffeldt-udtryk (Blicher 2001b, 141).

Sørgespillet Hakon Jarl fra Nordiske Digte, 1807, demonstrerer, at digteren Oehlenschläger kæmper imod tænkeren af samme navn, og i dets dansk-historiske sidestykke Palnatoke, 1809, sejrer tænkeren som et oplysningsmenneske. Grundtvig er så optaget af denne konflikt, at han helt overspringer det djærve fortællende digt "Thors Reise" (i Hildebrand-strofer) og det stilistisk avancerede læsedrama Baldur hin Gode (i græsk tragedieform), som begge også står i Nordiske Digte. ${ }^{127}$

$\mathrm{Nu}$ begynder Oehlenschlägers nedgang. Folkevisetragedien Axel og Valborg, 1810, tager sit tema i en rørende, men jordisk sværmende kærlighed i året 1162, og selv i Kristkirken i Nidaros (Trondhjem, hvor hele handlingen udspiller sig) sås ikke Kristus, så det højtidelige sted

${ }^{124}$ Claus Pavels i Laerde Efterretninger 1803, optr. i Oehlenschläger Studier 1972, 14-31.

125 Ifølge en boghandlerregning købte Grundtvig Poetiske Skrifter og Nordiske Digte den 12. februar 1808 (Fasc. 521.1).

${ }^{126}$ Det kan noteres, at Aladdin ikke for Grundtvig er det absolutte hovedværk i Oehlenschlägers ungdomsromantik (Lundgreen-Nielsen 1980, 442-443).

127 Læsedramaet om Baldur havde Grundtvig drøftet i Ny Minerva, 1807, og “Thors Reise" blev kort omtalt - og afvist som myte - i NM 1808 (US I, 318). 
misbrugtes til "verdslige Øiemed" (385). Kunstnerdramaet Correggio, 1811, er blevet en tro skildring af "Malerkonstens sørgelige Idræt [gøremål; resultat], at fremtrylle en Skygge af de forsvundne himmelske Skikkelser". I syngespillet Faruk, 1812 (dvs. dec. 1811), fremskrider "herlige Skikkelser" (fra 1001 Nat), men det er "Drømmebilleder der svæve i Luften, som om kun i en Feverden Ydmyghed straalende løfter sig over hovmodig Bram." 128 Tragedien Stcerkodder, 1812, fordømmes som "et livligt Spil uden heel Betydning". Oehlenschlägers romancer og sange samt prosaeventyret "Aly og Gulhyndy" i Digtninger, I, 1811, er "en mat Efterklang af de poetiske Skrifters herlige Toner" (385).

Grundtvig konstaterer således Oehlenschlägers uafvendelige dalen. I et højstemt afsnit opfordrer han ham til at "ihukomme sin første Kærlighed, og hvorfra han er falden, vende om og gøre sine forrige Gerninger" (385-386), for ellers vil Gud komme over ham og borttage hans lys, så han sorgfuld sidder i mørke. Dette er et frit udvidet citat af Johannes' Åbenbaring 2,4-5. Grundtvig slutter med en belæring af den art, som Oehlenschläger allerede privatissime $\mathrm{i}$ en brevveksling havde afvist fra ham et halvt år før: "Den Fred og den Roes, som Verden kan give, hvad har den at betyde, naar Verdens Skikkelse forgaaer" (386).

Sidst i sin egentlige tekst minder Grundtvig om Oehlenschlägers og sin egen oldnordiske digtning:

det lod hardtad, som det gamle Nordens Afguder med deres Skyggehær [hcer af genfoerd] vilde indtage Landet, der laa øde for [manglede] kristne Kæmper. Oehlenschläger slog Harpen for dem, og Grundtvig vilde opmane dem af deres Grave; Heste spændtes for de Stene, Fædrene havde væltet, Sproglærde stavede paa de Runer, de havde ristet, Krukkerne med deres Aske sankedes som Helligdomme over Herrens Tempel; ${ }^{129}$ Odin, Thor og Braga uddreve Zeus med Ares og Apollon, og kæmpede atter mod Kristus; Valhal løftede sig høit over Olympos, og der fandtes vel dem blandt Dannemarks Stridsmænd, som længtes mere efter Einheriers Gammen, end Himmerigs Salighed (389).

Dette kan være et udvortes og uforkasteligt vidnesbyrd om kristendommens forlis i nutiden, men det er også det kraftigst mulige billede af hedenskaben fra vor historie og vor olddigtning, som vi kan kontrastere med vor elendighed (efter det engelske bombardement 1807), "og i den Mening opløftede i det mindste Grundtvig et saadant, efterat han

\footnotetext{
${ }^{128}$ Trods nyskrevet musik af Weyse var opførelsen af Faruk ikke vellykket og blev efter Oehlenschlägers egen vurdering skyld i, at man fra nu af begyndte at dadle hans produktion (Oehlenschläger 1850, 21-22). Stykket blev i digterens levetid kun spillet 10 gange.

${ }^{129}$ Det nye danske nationalmuseum var i 1807 blevet grundlagt med en oldtidssamling på biblioteksetagen over Trinitatis Kirke (med indgang fra Rundetårns sneglegang). Den åbnedes dog først for offentligheden i 1819.
} 
havde faaet Syn paa Guddomsherligheden i Kristi Aasyn" (389). Det henviser til Optrin af Norners og Asers Kamp, bind 1 af Optrin af Nordens Koempeliv (udsendt efter bind 2), som var skrevet så godt som færdigt fra 1809 til midt i 1810. I de første måneder af 1811 supplerede Grundtvig sin handlingsgang fra Den Eldre Eddas heltekvad med en uhistorisk kristen missionær ved navn Thorkild, hvis prædikener omvender de overlevende vølsunger. Disse nye afsnit indgik derpå i satsen, som i hovedstaden blev styret af vennerne Christian Molbech, Povel Dons og Svend Hersleb fra begyndelsen af marts 1811 til udgivelsen lige efter jul.

På denne sidste side i VK 1812's egentlige tekst skriver Grundtvig to gange om sig selv i 3. person (i forbindelse med Oehlenschläger) og gør sig således til genstand for sin egen historieskrivning. Han slutter med et udblik til Norge, hvor en indfødt bondesøn på sin "selvgjorte Harpe" håbefuldt synger salmer med "gudelig Kraft og Sødhed" (389). ${ }^{130}$ En allersidste hilsen går dog til Frederik VI på grund af hans kongebud fra 1811 om oprettelse af et norsk universitet. "Bjergluften" omkring dette skal rense Nordens lunger, højtidssange skal som "Hjertets Røgoffer" søge til himmels, ${ }^{131}$ og røster skal "mod Syden og Vesten" (Danmark og England) ${ }^{132}$ "som en Fjeldtorden" forkynde, at synd fordærver, og at sødelig fred kun kommer ved evangeliet. Grundtvigs slutord er et "Amen".

${ }^{130}$ Det går sandsynligst på Hans Nielsen Hauge (1771-1824), som 1811 ff. skrev (tørre) salmer, der blev trykt i 1815 (Albeck 1955, 162). Hauge kom dog som retsforfulgt norsk bygdeprædikant ikke til at ændre væsentligt i den danske salmeskat (jf. Grundtvigs senere udtalelser om ham i Om Religions-Forfølgelse, 1842, US VIII, 468, i Den christelige Børnelcerdom, 1868, US IX, 536, og i Kirke-Speil, 1871, US X, 341).

${ }^{131}$ Grundtvig gør i sit billedsprog indirekte den danske konge til en Abel, hvis brændoffer Gud modtager. Dermed viser slutningen af $V K 1812$ tilbage til Grundtvigs skildring af menneskehedens begyndelse efter uddrivelsen af Eden (US II, 188).

${ }^{132}$ Syd og vest for Norge ligger Danmark, Slesvig-Holsten, Nordtyskland og Storbritannien. Det vidner om Grundtvigs Sverigesfobi, at han ikke forestiller sig nogen fjeldfrisk missionering sendt fra Kristiania øst- eller nordpå. 